\title{
ॠUSGS
}

science for a changing world

Geographic Analysis and Monitoring Program

\section{Land-Cover Trends in the Sierra Nevada Ecoregion, 1973-2000}

By Christian G. Raumann and Christopher E. Soulard

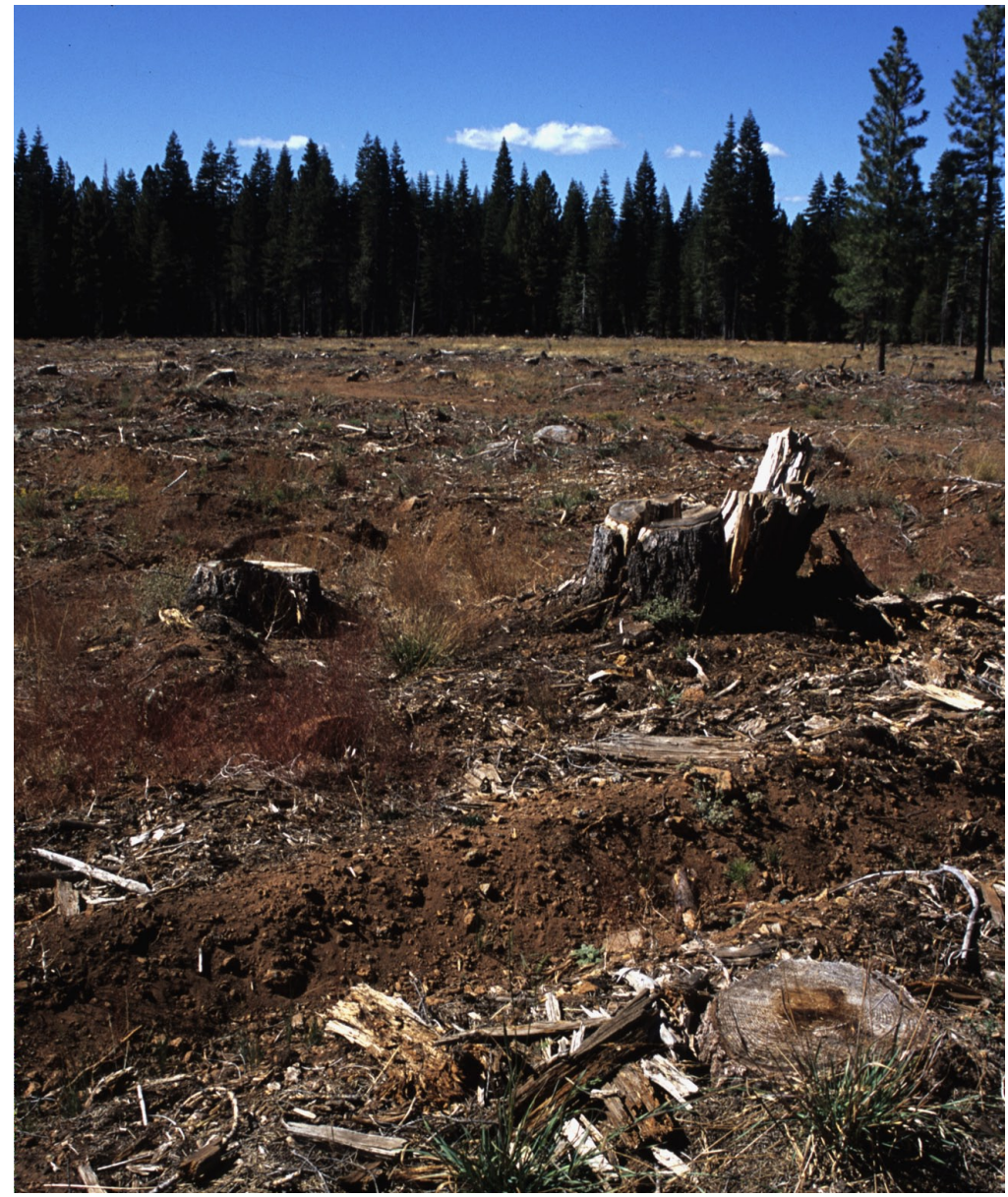

Scientific Investigations Report 2007-5011 


\section{U.S. Department of the Interior DIRK KEMPTHORNE, Secretary}

\section{U.S. Geological Survey Mark D. Myers, Director}

\section{U.S. Geological Survey, Reston, Virginia: 2007}

This report and any updates to it are available online at:

http://pubs.usgs.gov/sir2007/5011/

For product and ordering information:

World Wide Web: http//www.usgs.gov/pubprod

Telephone: 1-888-ASK-USGS

For more information on the USGS - the Federal source for science about the Earth, its natural and living resources, natural hazards, and the environment:

World Wide Web: http://www.usgs.gov

Telephone: 1-888-ASK-USGS

Any use of trade, product, or firm names in this publication is for descriptive purposes only and does not imply endorsement of the U.S. Government.

Although this report is in the public domain, permission must be secured from the individual copyright owners to reproduce any copyrighted materials contained within this report.

Cataloging-in-publication data are on file with the Library of Congress (http://www.loc.gov/).

Produced in the Western Region, Menlo Park, California

Manuscript approved for publication, January 23, 2007

Text edited by James W. Hendley II

Layout and design by Judy Weathers

FRONT COVER

Photograph of a recently clear-cut area in Plumas National Forest, Plumas County, Calif. 


\section{Foreword}

The U.S Geological Survey (USGS) Land Cover Trends research project is focused on understanding the amounts, rates, trends, causes, and implications of contemporary land-use and land-cover change in the United States. The project is supported by the USGS Geographic Analysis and Monitoring Program in cooperation with the U.S. Environmental Protection Agency (EPA) and the National Aeronautics and Space Administration (NASA).

Land-use and land-cover (LU/LC) change is a pervasive environmental process that modifies landscape characteristics and affects a broad range of socio-economic, biologic, and hydrologic systems. Understanding the impacts of LU/LC change on environmental systems requires an understanding of the rates, patterns, and driving forces of past, present, and future LU/LC change. The objectives of the Land Cover Trends project are to (1) describe the amount, rates, and trends of contemporary LU/ LC change by ecoregion for the period 1973-2000 for the conterminous United States, (2) document the causes, driving forces, and implications of change, and (3) synthesize individual ecoregion results into a national assessment of LU/LC change.

The Land Cover Trends research team includes staff from the USGS National Center for Earth Resources Observation and Science (EROS), Rocky Mountain Geographic Science Center, Eastern Geographic Science Center, Mid-Continent Geographic Science Center, and Western Geographic Science Center. Other partners include researchers at South Dakota State University, University of Southern Mississippi, and State University of New York College of Environmental Science and Forestry. 


\section{Contents}

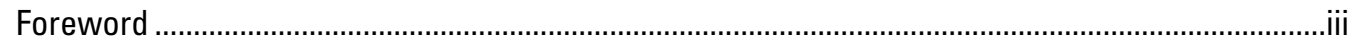

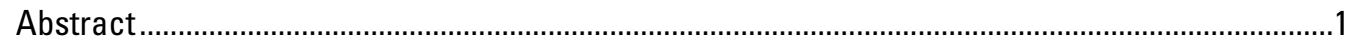

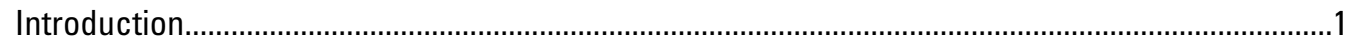

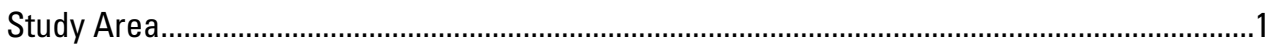

Historical Overview of Pre-1973 Land Use and Land Cover ...................................................2

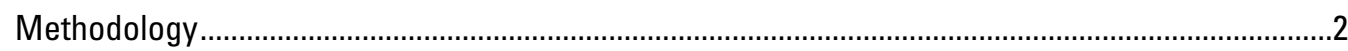

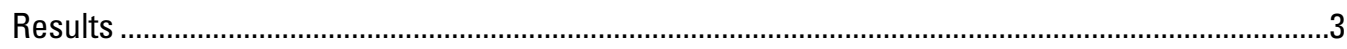

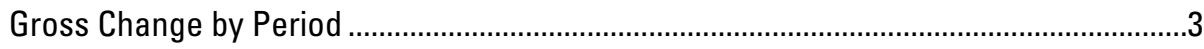

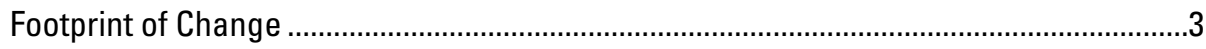

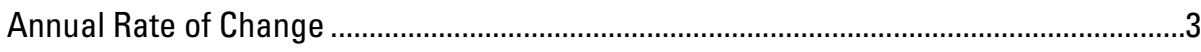

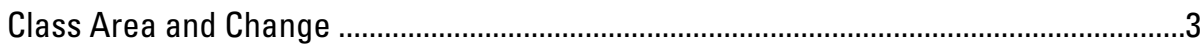

Most Common Conversions ............................................................................................ 4

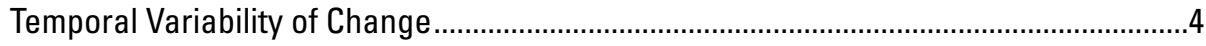

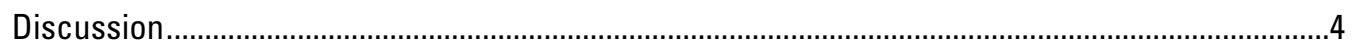

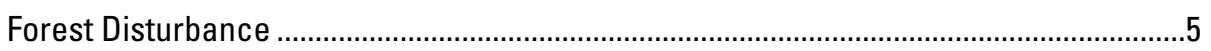

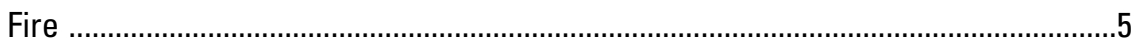

Timber Harvest ............................................................................................. 5

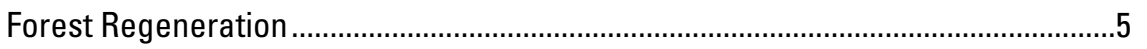

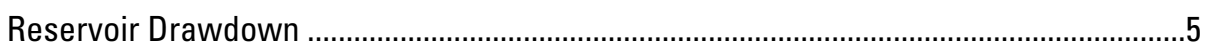

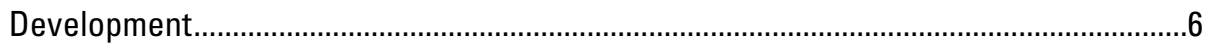

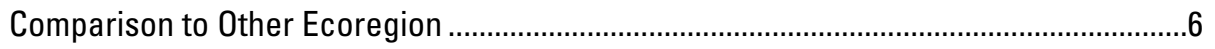

Relationship of Change to Spatially Explicit Variables ......................................................6

Sampling and Uncertainty Measurement..........................................................................

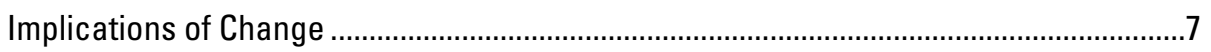

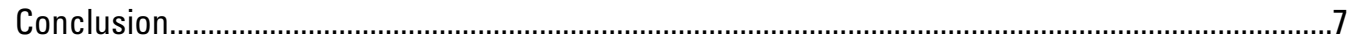

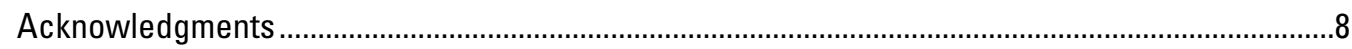

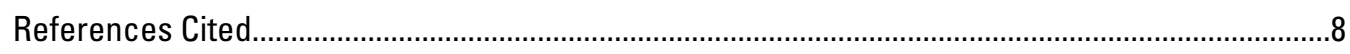

Appendix 1. Definitions of land use and land cover...........................................................................11

Appendix 2. Period contingency tables ............................................................................................ 12

\section{Figures}

1. Sierra Nevada and surrounding ecoregions................................................................................14

2. Land ownership in the Sierra Nevada ecoregion .....................................................................15

3. A single 100-km² sample block illustrating forest land-cover change.........................................16

4. Gross change by class by period in the Sierra Nevada ecoregion..............................................17

5. Temporal variability of individual land-use/land-cover classes ...................................................18

6. Forest area changed by fire, timber harvest, and regeneration during each period ...................19

7. Photo of an area undergoing succession after the Manter Fire in Sequoia National Forest.....20

8. Photo of a recently clear-cut area in Plumas National Forest.......................................................21

9. Comparison of timber harvest and land-cover change data........................................................22 
10. Photo of forest regeneration after seeding in Plumas National Forest.......................................23

11. Photo of lowered lake levels at Courtright Reservoir in Sierra National Forest .........................23

12. Photo of new residential construction in Franktown, Nev., north of Carson City .......................24

13. Photo of commercial construction along the access road to the Squaw Valley resort area

14. Average annual rates of change by period for selected ecoregions in the Western United States

15. Example of extensive land-cover change within a single sample block caused by wildfire

\section{Tables}

1. Land-use/land-cover class area by date as a percent of Sierra Nevada ecoregion total area

2. Most common land-use/land-cover conversions from 1973-2000 ….............................................27

3. Rates of land-use/land-cover change grouped according to general process............................28

4. Potential explanatory variables and corresponding data sources .............................................29

5. Results of multiple linear regression analysis for the response variable mean gross change.

6. Gross change by period and the corresponding margins of error at an 85-percent confidence level 


\title{
Land-Cover Trends of the Sierra Nevada Ecoregion, 1973-2000
}

\author{
By Christian G. Raumann and Christopher E. Soulard
}

\section{Abstract}

The U.S. Geological Survey has developed and is implementing the Land Cover Trends project to estimate and describe the temporal and spatial distribution and variability of contemporary land-use and land-cover change in the United States. As part of the Land Cover Trends project, the purpose of this study was to assess land-use/land-cover change in the Sierra Nevada ecoregion for the period 1973 to 2000 using a probability sampling technique and satellite imagery. We randomly selected $36100-\mathrm{km}^{2}$ sample blocks to derive thematic images of land-use/land-cover for five dates of Landsat imagery $(1973,1980,1986,1992,2000)$. We visually interpreted as many as 11 land-use/land-cover classes using a 60-meter minimum mapping unit from the five dates of imagery yielding four periods for analysis. Change-detection results from post-classification comparison of our mapped data showed that landscape disturbance from fire was the dominant change from 1973-2000. The second most-common change was forest disturbance resulting from harvest of timber resources by way of clear-cutting. The rates of forest regeneration from temporary fire and harvest disturbances coincided with the rates of disturbance from the previous period. Relatively minor landscape changes were caused by new development and reservoir drawdown. Multiple linear regression analysis suggests that land ownership and the proportion of forest and developed cover types were significant determinants of the likelihood of direct human-induced change occurring in sampling units. Driving forces of change include land ownership, land management such as fire suppression policy, and demand for natural resources.

\section{Introduction}

In this report we present an assessment of land-use and land-cover (LU/LC) change in the Sierra Nevada ecoregion for the period 1973-2000. The Sierra Nevada ecoregion is one of 84 Level-III ecoregions defined by the Environmental Protection Agency (EPA, 1999; Omernik, 1987). Ecoregions have been designed to serve as a spatial framework for environmental resource management and denote areas that contain a geographically distinct assemblage of biotic and abiotic phe- nomena including geology, physiography, vegetation, climate, soils, land use, wildlife, and hydrology (Gallant and others, 2004). We used the established Land Cover Trends methodology (Loveland and others, 2002) to estimate LU/LC change using a probability sampling approach and change-detection analysis of thematic LU/LC images derived from Landsat satellite imagery.

\section{Study Area}

The Sierra Nevada ecoregion covers approximately 52,872 square kilometers $\left(\mathrm{km}^{2}\right)$ with the majority of area (98 percent) in California and a small portion (2 percent) in Nevada (fig. 1). The Sierra Nevada ecoregion (SNE) is generally orientated from north to south and is in essence defined by the Sierra Nevada physiographic province, which separates the California Central Valley to the west from the Great Basin to the east. The Sierra Nevada is a granitic batholith, much of which is exposed at higher elevations, with a gradual western slope and a generally steep eastern escarpment.

The climate of the SNE is primarily Mediterranean characterized by cool, wet winters and long, dry summers. Most areas of elevation above 2,100 meters have a Boreal climate, and the highest elevations, typically above 3,600 meters, have an Alpine climate. Precipitation increases with elevation from west to east as storm systems moving from the west are subject to orographic uplift causing rain and snowfall. As the western slope of the SNE extracts precipitation from storm systems, a strong rainshadow results and limits precipitation on the steep eastern slope. This climatic gradient plays a significant role in determining type and distribution of ecological communities. In order to provide water resources for the growing populations in arid, low-elevation areas of California and Nevada, numerous reservoirs on the western and eastern slopes of the SNE collect runoff from the winter snow pack.

The general Sierra Nevada region, which is slightly larger than the SNE proper, is home to more than 3,000 native plant species, of which 405 are endemic, 218 are rare and endemic, and 168 are rare and not endemic (Shevock, 1996). Climate, elevation, and soil type greatly influence the diversity and distribution of vegetation that makes up forests, meadows, chaparral, and alpine land-cover types. The western and eastern boundaries of the SNE are marked in part by the appear- 
ance of the broad conifer zone. Moving up in elevation on the western slope, ponderosa pine mixed with black oak and other hardwoods appear first giving way to the commercially valuable mixed-conifer forest, which transitions into white and then red fir forests as elevation increases. Pinon pine and juniper woodlands are found at the base of the eastern slope of the SNE, replaced by mixed pine forests at higher elevations. The subalpine zone is a mixture of pine, hemlock, and juniper species. Above the subalpine is the cold and dry alpine zone characterized by low shrubs and cushion plants (SNEP Science Team and Special Consultants, 1996a).

The largest city in the SNE is South Lake Tahoe (2005 pop. 24,059), which is located on the shore of the largest alpine lake in North America. The next largest municipalities are Susanville (2005 pop. 18,324), Grass Valley (2005 pop. 13,006), Mammoth Lakes (2005 pop. 7,617), and numerous smaller rural communities located throughout (State of California, Department of Finance, 2005). Economies of these cities and towns largely depend on a steady flow of tourists.

Public lands make up 84.5 percent $\left(444,677 \mathrm{~km}^{2}\right)$ of the SNE with the majority (68.3 percent) managed by the U.S. Forest Service (USFS) as National Forests, with 21.8 percent of these USFS lands designated as wilderness (fig. 2). The National Park Service (NPS) manages 13.0 percent of the SNE as Yosemite, Sequoia, Kings Canyon, and Lassen Volcanic National Parks. Land holdings by the Bureaus of Land Management, Reclamation, and Indian Affairs cumulatively account for 2.4 percent of the SNE. In addition to federal lands, the State of California manages 0.7 percent $\left(3,701 \mathrm{~km}^{2}\right)$ of the SNE along with smaller holdings (less than 0.5 percent) by the State of Nevada and local cities and counties. Privately owned lands make up 15.5 percent $\left(8,195 \mathrm{~km}^{2}\right)$ of the SNE.

\section{Historical Overview of Pre-1973 Land Use and Land Cover}

European settlers began immigrating to the SNE in the early 1800 s, ushering in a period of industrial resource use that affected land-cover conditions to varying degrees. The history of resource use can be followed through the land-use patterns related to gold and mineral extraction, grazing and agriculture, timber harvests, water diversions, and recreational and residential development. Starting with the discovery of gold in 1848 in the Sierra Nevada foothills west of the SNE, many of the periods of resource use in and around the Sierra Nevada can be described as boom-and-bust cycles. Throughout the late 1880s the demands of gold mining activities as well as residential and commercial development in the Central Valley and San Francisco area resulted in the harvest of thousands of acres of lower-elevation SNE timber each year for construction (SNEP Science Team and Special Consultants, 1996b).

The $20^{\text {th }}$ century marked a new phase of SNE history in which resource use became increasingly regulated. Forest and rangelands were protected through creation and expansion of national forests and parks. Laws and administrative policies such as the Wilderness Act of 1964, National Environmental Policy Act of 1969 (NEPA), and National Forest Management Act of 1976 (NFMA) provided a mechanism to manage national forests. Furthermore, other environmental laws, annual appropriations legislation, and administrative policies relating to fire and fuels guide resource use and likely have significant environmental effects in the SNE (Ruth 1996).

By the 1950s, California's growing urban population greatly increased the demand for wood, water, hydroelectricity, and recreational opportunities from the SNE. Timber harvesting surged and continued until the economic recession in the early 1980s. Water is considered the SNE's most valuable resource (SNEP Science Team and Special Consultants, 1996b). Eighty percent of present reservoir capacity was completed after 1950. Concrete dams and the associated reservoirs control the flow of water in nearly every major river basin in the SNE and are managed to provide municipal water supplies and hydroelectric power. Major highways and ski resorts were constructed in the 1950s and 1960s to meet the demand for year-round recreation (SNEP Science Team and Special Consultants, 1996b).

Frequent fires of low to moderate intensity were an integral component of the preindustrial development of SNE ecological communities. Fires created a cycle of disturbance and succession that floral and faunal communities have adapted to and often require to propagate and thrive (Skinner and Chang, 1996). By the late twentieth century the regional fire regime had greatly changed primarily due to logging during the settlement period and effective fire suppression activities mandated by State and Federal policy since the 1920s. As a result, fires were less frequent and more severe (Skinner and Chang, 1996). Forest density increased and contributed to higher tree mortality due to greater intertree competition, insect attack, disease, and storm damage (Oliver and others 1996). These conditions contribute to fuels and increased fire hazard as well as the likelihood of high-severity fire (Manley and others 2000). A shift to a warmer and moister climate may have also contributed to this altered fire regime by reducing winter severity and providing a longer growing season (McKelvey and others, 1996; Stine, 1996). Furthermore, some SNE shrub communities, such as montane chaparral, require recurring high-severity fire for continued establishment and persistence. Fire suppression facilitated conifer encroachment into chaparral stands, leading to eventual replacement of chaparral by forest (Nagel and Taylor, 2005).

\section{Methodology}

We estimated the amount and rates of LU/LC change in the SNE using a random sample of $36100-\mathrm{km}^{2}(10-\mathrm{km}$ by $10-\mathrm{km})$ blocks allocated across the SNE (fig. 1). We visually classified up to 11 classes of LU/LC (for example, water, developed, forest; see appendix 1) from five dates (1973, 1980, 1986, 1992, and 2000) of archived Landsat Multispectral Scanner (MSS), Thematic Mapper (TM), and Enhanced Thematic Mapper Plus (ETM+) satellite imagery using a 360- $\mathrm{m}^{2}$ (60-m x 60-m cell 
size) minimum mapping unit (MMU). In addition to on-screen visual interpretation techniques, we used historical aerial photographs, topographic maps, and various ancillary data to aid in image interpretation. Our LU/LC mapping effort yielded five individual dates and four discrete periods for analysis. We then used post-classification comparison (that is, change detection) of the five dates of thematic LU/LC data for each sample block to estimate the amount of area changed and the context of change for the entire SNE along with corresponding margins of error at an 85 percent confidence level to describe sampling accuracy. A full explanation of Land Cover Trends project methodology is provided by Loveland and others (2002).

\section{Results}

This section presents the results of post-classification comparison of the multidate LU/LC data. We report these estimates of LU/LC change in the context of the entire SNE area based on the sampled data. Figure 3 illustrates an example of mapped LU/LC change for one sample block in the SNE.

\section{Gross Change by Period}

Gross change describes the total amount of land that underwent any type of change during a single multi-year period and is perhaps the most general statistic resulting from post-classification comparison of thematic LU/LC data. The greatest amount of gross change occurred from 1992-2000, as 3.9 percent of the SNE $\left(2,051 \mathrm{~km}^{2}\right)$ underwent LU/LC change during this period. Gross change for the remaining three period was as follows: 1.6 percent $\left(864 \mathrm{~km}^{2}\right)$ from $1986-1992$, 0.8 percent $\left(399 \mathrm{~km}^{2}\right)$ from $1980-1986$, and 0.9 percent $(452$ $\mathrm{km}^{2}$ ) from 1972-1980.

\section{Footprint of Change}

The overall areal extent, or "footprint," of LU/LC change from 1973-2000 was 4.9 percent $\left(2,591 \mathrm{~km}^{2}\right)$, which means that 4.9 percent of the SNE underwent LU/LC change during at least one of the four multiyear periods that make up the entire 27-year (yr) study period. Of this 4.9 percent footprint, 3.2 percent of the SNE changed during only one period, 1.5 percent changed during two periods, and 0.3 percent change during three periods.

\section{Annual Rate of Change}

The estimated average annual rate of LU/LC change is calculated by normalizing each period's gross change by the number of years in that period. Normalizing gross change by year effectively allows comparison of the amount of change in each period when periods are of varying duration $(6,7$, or 8 years). It is important to note that the resulting rates-of-change, although presented as per-year rates, are only an estimate and should be viewed as a description of the period and not of the individual years within the period. The estimated average annual rate of LU/LC change for the entire 27-yr study period from 1973-2000 was 0.3 percent/yr, which means that on average 0.3 percent of the SNE changed each year. However, the annual rate of change has not been constant during the 27 -yr study period as shown by the estimated average annual rates for the four periods. From 1973-1980 and from 1980-1986, change occurred at identical rates of $0.1 \mathrm{percent} / \mathrm{yr}$. The annual rate of change increased to 0.3 percent/yr from 1986-1992 and continued to increase to 0.5 percent/yr from 1992-2000.

\section{Class Area and Change}

Our results show that in 2000 the SNE was dominated by forest cover (70.1 percent) with grassland/shrubland (20.4 percent), barren (2.7 percent), nonmechanically disturbed (2.4 percent), wetland ( 2.2 percent), and water (1.1 percent) making up the remainder of land cover (table 1). Developed, mining, agriculture, snow/ice, and mechanically disturbed LU/LC types each made up less than one percent of the SNE. Land-use/landcover classes that underwent the greatest net change (that is, total area gained minus total area lost) in relation to total SNE area since 1973 were forest (3.4 percent decrease), grass/shrubland (1.1 percent increase), and nonmechanically disturbed (2.3 percent increase). Although the developed and agriculture classes each makeup less than 1 percent of the SNE, the developed class underwent the greatest increase in area (16.6 percent) and agriculture underwent the greatest decrease in area (5.5 percent) in relation to their respective total class area not considering the transitional nonmechanically disturbed class.

The net change values as a percentage of SNE area at the beginning (1973) and end (2000) dates of the study period in table 1 show little variability and may seem to indicate stability. Net change values often serve to effectively mask LU/LC dynamics. For example, a class may gain $100 \mathrm{~km}^{2}$ and at the same time lose $100 \mathrm{~km}^{2}$ which would yield a net change of 0 $\mathrm{km}^{2}$. Reporting the net change value of $0 \mathrm{~km}^{2}$ misses much of the story of landscape change. However, analysis of gross change (that is, area gained and lost) by individual LU/LC classes by period shows classes have fluctuated throughout the 27 -yr study period to a greater degree than net change values may indicate. Figure 4 shows that the forest, grass/shrubland, mechanically disturbed, and nonmechanically disturbed classes were the most dynamic from 1973-2000. The transitional characteristic of the mechanically disturbed class is also illustrated as area gained $\left(810 \mathrm{~km}^{2}\right)$ and nearly equals area lost $\left(787 \mathrm{~km}^{2}\right)$ from 1973-2000. Land-cover change was clearly at its peak during the period from 1992-2000 when gains and losses were generally greatest for the four most dynamic classes.

Figure 5 shows another technique to illustrate the temporal variability of individual LU/LC classes. Each graph shows the dynamics of a class measured along an annual scale. The cumulative area gained by a class shows the amount of land that is converted to that class from any other class. The cumulative 
area lost by a class shows the amount of land that is converted from that class to any other class. As the next section will show, breaking down LU/LC change into contextual conversions is an even more effective way to illustrate LU/ LC dynamics.

\section{Most Common Conversions}

All individual LU/LC conversions between classes were ranked by summing the total area changed during each of the four periods:

Ranking value $=$

Area $\Delta_{1973 \text { to } 1980}+$ Area $\Delta_{1980 \text { to } 1986}+$ Area $\Delta_{1986 \text { to } 1992}+$ Area $\Delta_{1992 \text { to } 2000}$

Each conversion documents land changing from one class to another (for example, forest to developed) and shows the direction of change. Table 2 shows each individual conversion ranked from greatest to least area converted. The most common individual conversions describe the disturbance of forested lands by mechanical (that is, clear-cuts) and nonmechanical (that is, fire) means. The most common conversion was that of $1404.3 \mathrm{~km}^{2}$ of forest to the nonmechanically disturbed class which accounted for 37.1 percent of all conversions. The second most common conversion was that of 783 $\mathrm{km}^{2}$ forest to the mechanically disturbed class accounting for 20.7 percent of all changes. Conversion of mechanically and nonmechanically disturbed lands to the grass/shrubland class ( $753 \mathrm{~km}^{2}$ and $307 \mathrm{~km}^{2}$, respectively) were the two next most common conversions and represented the process of vegetation regeneration after clear-cutting or fire. Similarly, conversion of grass/shrubland to forest $\left(303 \mathrm{~km}^{2}\right)$ represented an intermediate stage of the regeneration cycle. A much less common but noteworthy conversion was that of water to mechanically disturbed $\left(26 \mathrm{~km}^{2}\right)$, which accounted for 0.7 percent of all individual conversions. This conversion of indicates surface-level fluctuations of reservoirs in the SNE.

Table 2 also provides a summary of similar conversions that were aggregated based on how a single to or from class was affected. From 1973-2000 1,545 km² of vegetation class (forest, grass/shrubland, and wetland) area was converted to the nonmechanically disturbed class. Fire caused these conversions. Total vegetation regeneration after disturbance is shown by the conversion of nonmechanically disturbed lands to vegetation classes (forest and grass/shrubland) and conversion of mechanically disturbed lands to vegetation classes (forest and grass/shrubland) for aggregated totals of $787 \mathrm{~km}^{2}$ and $317 \mathrm{~km}^{2}$, respectively. Several classes were converted to the developed class for an aggregated total of $21 \mathrm{~km}^{2}$.

\section{Temporal Variability of Change}

Rates of LU/LC change throughout the 27-yr study period fluctuated (table 3 ). The rate of disturbance from burning as represented by the conversion of vegetated lands to the non- mechanically disturbed class was $14 \mathrm{~km}^{2} / \mathrm{yr}$ averaged from 1973-1980, decreasing to less than $1 \mathrm{~km}^{2} / \mathrm{yr}$ from 1980-1986, and increasing to $21 \mathrm{~km}^{2} / \mathrm{yr}$ during the $1986-1992$ period. During the final period from 1992-2000, the rate greatly increased to an average of $163 \mathrm{~km}^{2} / \mathrm{yr}$. Of all lands burned between 1973 and 2000, 91 percent were forested and 9 percent were covered by grass/shrubland. The rate of vegetation regeneration after fire represented by the conversion of land from nonmechanical disturbance to vegetation classes reflects the rate of fire disturbance. Regeneration increased during the period following a period of higher rates of fire disturbance and decreased after a period of lower rates of fire disturbance. Between 1973 and 2000, lands disturbed by fire changed to grass/shrubland 97 percent of the time and to forest 3 percent of the time during the period immediately following disturbance.

Disturbance from clear-cutting as represented by the conversion of forest to the mechanically disturbed class occurred at an average rate of $24 \mathrm{~km}^{2} / \mathrm{yr}$ from 1973-1980. Clear-cutting slightly increased to an average rate of $25 \mathrm{~km}^{2} / \mathrm{yr}$ from 1980 1986 , although for a shorter period of time (6 years rather than 7). Change continued increasing to $70 \mathrm{~km}^{2} / \mathrm{yr}$ from 1986 to 1992 and then decreased to $32 \mathrm{~km}^{2} / \mathrm{yr}$ from 1992-2000. The rate of vegetation regeneration reflects the rate of clear-cutting, increasing after a period of higher rates of clear-cutting and decreasing after a period of lower rates of clear-cutting. Between 1973 and 2000, clear-cut lands changed to grass/ shrubland 96 percent of the time and to forest 4 percent of the time during the period immediately following disturbance. An intermediate stage of forest regeneration represented by grass/ shrubland changing to forest occurred at varying rates with an average of $11 \mathrm{~km}^{2} / \mathrm{yr}$ from 1973-2000. Figure 6 shows the rates of disturbance from fire and clear-cutting and the corresponding rates of regeneration from each process.

The rate of conversion of area classified as water to the mechanically disturbed class varied between periods with the highest average rate during the period 1986-1992 (2 km²/yr). We did not detect any land-cover conversions to the developed class during the 1973-1980 and 1980-1986 periods. From 1986-1992, conversions to developed occurred at an average rate less than $1 \mathrm{~km}^{2} / \mathrm{yr}$, and from 1992-2000 they occurred at a rate of $3 \mathrm{~km}^{2} / \mathrm{yr}$.

\section{Discussion}

In this section we discuss LU/LC dynamics in the SNE based on the aforementioned estimates of the amounts and rates of LU/LC change, existing literature, and knowledge of the SNE based on observations made during field reconnaissance. The causes of the LU/LC changes and trends form the framework for discussing these changes. When possible, we have identified the likely driving forces of change and compared LU/LC change estimates with independent data sources when available and appropriate. 


\section{Forest Disturbance}

\section{Fire}

Landscape disturbance from fire was represented by lands classified as forest, grass/shrubland, or disturbed changing to nonmechanically disturbed lands and was the dominant change that we detected throughout the 27-yr study period (fig. 7). These burned areas are typical of the fire regime during the study period of low-frequency, high-severity fires that overwhelm suppression efforts and result in stand replacement. High-severity fires result in the mortality of small and subcanopy trees as well as many to most overstory trees (Skinner and Chang, 1996). Low- and moderate-severity fires that usually do not kill large trees would likely not be mappable because the resulting level of disturbance does not meet criteria for classifying a forested area as nonmechanically disturbed (appendix 1) and/or may not be visible in the satellite imagery.

We used a dataset of fire perimeters developed by California Department of Forestry/Fire and Resource Assessment Program (CDF/FRAP) with contributions from the USFS, BLM, and NPS to help interpret the Landsat imagery. This dataset contains regions (polygons) representing fire perimeters from 1898-2000 and includes fire name, tracking agency, cause, and date of ignition. All of the fires we detected generally coincided spatially with fire locations and temporally with ignition dates from the CDF/FRAP dataset. Furthermore, although the fires we detected appear in the CDF/FRAP dataset, we did not detect all fires identified by the CDF/FRAP dataset occurring within our samples in the imagery for the study period. Due to the variety of fire characteristics, including burn-area size and severity of disturbance, not all fires in the CDF/FRAP dataset were visible in the imagery or met our mapping criteria.

\section{Timber Harvest}

All instances of forest cover changing to mechanically disturbed lands represent areas harvested by clear-cutting (fig. 8). Our study period begins at the same time as the implementation of the CDF's Z'berg-Nejedly Forest Practice Act (1973) that introduced improved silviculture standards with mechanisms for inspection and enforcement (Helms and Tappeiner, 1996). Figure 9 compares our LU/LC change data documenting timber harvest with California timber harvest statistics from USFS and tax data. The USFS and tax harvest data includes all counties with area in the Sierra Nevada and is a slightly larger than the full extent of the SNE. The temporal trends of the two separate timber harvest indicators are similar for each ownership class as well as for the combined total. Between 1980 and 1986, both the amount of timber (fig. $9 A$ ) and the amount of land-cover change directly resulting from timber harvest (fig. 9B) decline probably due to a shift in the harvest pattern shifting from old growth to young growth stands as old growth harvesting restrictions increased and young growth stands matured (Stewart,
1996). Both timber harvest indicators showed an increasing trend from 1986-1992 as demand and prices increased for lower grade timber that was once considered economically unfeasible to harvest. In general, private timber lands are at lower elevations and of higher site quality whereas USFS timber lands are at higher elevations and usually of lower site quality (that is, primarily lower soil productivity) (Stewart, 1996). This elevation-related ownership distribution may explain the disparity in figure 9 between private timber harvest area shown by the two indicators, as many privately owned timber sites included in the tax data may fall outside of the SNE boundary. As a result, our land-cover change data represents less private timber harvest than the tax data.

\section{Forest Regeneration}

Burned and clear-cut areas are temporary land-cover types that transition to various vegetation land-cover classes at differing rates in the absence of other disturbances. Burned areas usually changed to grass/shrubland and represented the early stages of secondary succession. This is the LU/LC conversion observed most commonly during the period immediately following fire disturbance. In a few cases, nonmechanically disturbed lands changed to forest rather than grass/shrubland in the period following the disturbance. These cases may indicate faster regeneration rates due to more favorable site quality, varying fire severity, or forest management policies. These cases may also be a function of the varying lengths (that is, 6 to 8 years) of the study periods.

Forest regeneration was likely driven by management activities that influenced the natural dynamics of succession. Land managers in the SNE usually used seed to regenerate forest stands after clear-cutting (fig. 10), although replanting may have been used when prompt regeneration was required. Private landowners commonly relied on natural regeneration (Helms and Tappeiner, 1996). In most cases, Federal and State regulations require that sites cleared for timber production must be stocked with seedlings within 3 to 5 years of stand removal, and so managers often choose to plant in order to ensure compliance. Managers also plant rather than seed sites after high-severity fires when pine seed is not available and competition with shrubs and shade-tolerant tree species would prevent natural regeneration of pine species. Rapid establishment of grasses, herbs, and shrubs usually follows disturbance from fire or logging and often must be controlled in order for conifers to successfully regenerate (Tappeiner and McDonald, 1996).

\section{Reservoir Drawdown}

We classified barren shorelands that were exposed due to reservoir drawdown as mechanically disturbed because the lowering process was primarily driven by human forces (water and hydroelectric power demands), although environmental conditions such as drought may have influenced where the responsible utility companies set the height of reservoir water 
levels. SNE reservoirs' surface levels vary seasonally because winter snowmelt fills reservoirs during the late spring and early summer months. Numerous reservoirs were captured within our sample blocks, and evidence of reservoir drawdown was apparent in southern Sierra Nevada reservoirs, such as Florence Lake, Mammoth Pool Reservoir, and Courtright Reservoir (fig. 11).

Reservoir storage data from the California Department of Water Resources Data Exchange Center (CDEC) provide insight into the temporal variability of reservoir drawdown. Most of our imagery and field photographs were acquired in mid to late summer, so we analyzed reservoir storage data for the month of September. Storage data for 1983 and 2000 for reservoirs in the Upper San Joaquin River watershed (southern SNE) show a drop in storage from 63 percent of capacity in 1983 to 50 percent of capacity in 2000. CDEC storage data do not account for year-to-year fluctuations, but the general trend of decreasing September storage agrees with our results, which show a detectable drop from 1986-1992 and from 1992-2000.

\section{Development}

We detected little new development in the SNE between 1973 and 2000. Although Duane (1996) states that the population of the Sierra Nevada doubled between 1970 and 1990, most of this documented new development occurred near the historical centers of the gold rush in towns that lie to the west and outside of the SNE boundary in the Southern and Central California Chaparral and Oak Woodland ecoregion. In the case of the Lake Tahoe basin, which contains the most urbanized areas of the SNE, the footprint of development was established by 1969 prior to our study period. After 1969, development has greatly slowed due to the constraints of increased public ownership through intensive State and Federal land acquisition programs, as well as stringent regulations on new development aimed at alleviating adverse environmental impacts in the Lake Tahoe basin. Most of the small amount of new development we detected in the SNE occurred along the western and eastern boundary (fig. 12) of the ecoregion in the form of commercial development to support tourism (fig. 13).

\section{Comparison to Other Ecoregions}

In comparison with the rates of LU/LC change for other ecoregions in the Western United States that have undergone Land Cover Trends analysis as of January 2006 (fig. 14), the SNE is distinctive in that it is the only ecoregion that exhibited a significant trend of increasing rate of change throughout the entire study period. Rates as well as footprints of change were significantly greater in the Coast Range and Puget Lowland ecoregions, which were both dominated by extensive timber harvest and some urban development. In comparison to these other ecoregions, change in the SNE can be described as low to moderate.

\section{Relationship of Change to Spatially Explicit Variables}

We used multiple linear regression analysis to explore what spatially explicit environmental and human variables may have a statistically significant relationship to LU/LC change in the SNE. The dependent response variable in our model was mean gross change for each of the 36 sample blocks, which was derived by calculating the average of the gross change results for each of the four multi-year periods that make up the entire $27-y r$ study period. The potential explanatory variables, which were derived from multiple sources, are listed in table 4 . We selected these variables based on knowledge of the SNE and data availability.

Initial multiple regression analysis testing of all eight explanatory variables showed a weak relationship to mean gross change values that included all changes with the coefficient of determination $\left(\mathrm{R}^{2}\right)$ being less than 0.10 . However, eliminating the change resulting from fire and including only changes from directly human-induced changes (primarily timber harvest, relatively small amounts of reservoir drawdown and development) in the mean gross change values saw a strengthening in the relationship between the independent variables and mean gross change $\left(\mathrm{R}^{2}=0.40\right)$. Removing the inherently random wildfire events in the SNE may explain the improvement in goodness of fit. The t-value for each independent variable from the initial regression showed that many of these variables do not have a significant influence on LU/LC change. A combination of three variables, percent private ownership, average percent forest cover, and average developed cover, provided the best model which accounted for 58 percent $\left(\mathrm{R}^{2}=0.58\right)$ of the variability of human-induced mean gross change (table 5 ).

Although there is a great deal of variation evident in this analysis, proportion of forest cover, developed cover, and land ownership appear to be determinants of the likelihood of direct human-induced change within sample blocks located throughout the SNE. Percent private ownership is the variable with the highest degree of influence on the mean gross change in the model (t-value of 5.18). It is possible that these regression results do not necessarily indicate that direct human-induced changes occur mostly on private lands, but may suggest that these changes are more likely to occur on Federally owned lands that are located in close proximity to private lands or exhibit a patchwork pattern of ownership. The average percent forest and developed cover variables have similar degrees of influence (t-values of 2.34 and -2.01, respectively) with forest cover having a positive correlation and developed cover having a negative correlation to mean gross change. Because timber harvesting is the dominant change measured by the mean gross change values, it seems reasonable that areas with a greater amount of forest cover are more likely to undergo change. The inverse relationship of developed cover to change in the SNE may show that change, such as timber harvest, is more likely to occur away from developed areas. 
Results of this simple statistical analysis suggest that specific spatially explicit variables have a unique relationship to LU/LC change in the SNE. We will pursue further quantitative analysis of determinants and driving forces of LU/LC change in the SNE and other ecoregions in the Western United States. We would like to expand our analysis to link metrics of LU/LC change to spatially as well as nonspatially explicit variables related to management and policy, economics, and environmental conditions. Furthermore, analysis on a cell-by-cell basis within each sample block will allow a more detailed examination of change.

\section{Sampling and Uncertainty Measurement}

The Land Cover Trends project uses a probability sampling design to provide estimates of LU/LC change for four time periods. The precision of our estimates for gross change by period (that is, percent area of the ecoregion that underwent any type of change between two dates) is described by a margin of error at an 85 percent confidence level (table 6). For the SNE, all periods had a margin of error equal to or less than +/- 0.5 percent, except for the period 1992-2000, which had a margin of error of $+/-2.5$ percent. The relatively high margin of error from 1992-2000 is likely the result of inadequate sampling density given the spatial distribution of change within the SNE. More specifically, most of the gross change during this period can be attributed to high amounts of fire occurrence, which was not evenly distributed throughout the SNE (fig. 15). In general, ecoregions with evenly distributed change require fewer sample blocks, while ecoregions with clustered and clumped areas of change require more sample blocks to reduce sampling uncertainty. We are currently examining methods for improving the precision of our estimates, including post-stratified and regression estimation. For additional information on the Land Cover Trends sampling design and the inherent uncertainties of sampling estimates, see Stehman and others (2003) and Loveland and others (2002).

\section{Implications of Change}

Fires that cause land-cover change alter landscape structure by promoting a relatively coarse-grained landscape pattern, increasing soil erosion, affecting nutrient cycling, and stimulating plant growth, which benefits faunal communities (Chang, 1996). Furthermore, fire can have physical, chemical, and biological effects on soils including loss of soil structure, loss of nutrients, and mortality of soil organisms (Poff, 1996). Areas affected by high-intensity fires are often characterized by increased adverse effects due to greater burn intensity (DeBano, 1979 as cited in Poff, 1996).

Soil productivity in areas of land-cover change resulting from timber harvest may be affected through erosion, displacement, compaction, biomass export, and leaching (Poff, 1996).
Additionally, these effects are likely to be greater in areas of detectable land-cover change that result from clear-cutting in comparison to areas harvested through partial removal of forest stands (Poff, 1996). After an area undergoes timber harvest, land managers often apply a variety of practices to prepare the site for regeneration, such as piling slash by mechanical means and burning slash piles. Long-term soil productivity is potentially impacted during the preparation period through manipulation of the forest floor, especially after clear-cutting operations (Poff, 1996).

The possible ecological implications of the relatively small amount of natural land-cover conversion to residential and commercial development that we detected from 19732000 are numerous. Direct effects of land conversion to development include reduction of total habitat area, reduction of habitat patch size, increased habitat fragmentation, and isolation of habitat patches by roads, structures, and fences (Duane, 1996). Impervious-surface area is a primary landcover component of the developed land-use class and occurs in the form of roads, parking lots, driveways, building footprints, and other manmade features. Impervious surfaces prevent ground percolation and effectively increase runoff velocity, peak flows, stream-water temperature, erosion potential, and non-point source pollutant concentrations (Slonecker and others, 2001, Brabec and others, 2002).

\section{Conclusion}

Land-use and land-cover change has played an important role in shaping the landscape of the SNE. The results of our analysis show quantified trends in LU/LC change resulting from fire, timber harvest, development, and reservoir drawdown for the period 1973-2000. Extensive public land ownership, which continues to increase in areas such as the Lake Tahoe basin, will almost assuredly dictate the future amounts and geographic distribution of directly humaninduced LU/LC change such as timber harvest and urban development. Additionally, fire will undoubtedly continue to leave its mark on the SNE landscape as it has in the past.

The description of the trends of LU/LC change presented here highlights the benefits of multi-temporal analysis and, specifically, the uniqueness of the results produced using USGS Land Cover Trends project methodology. As the project team produces results for additional ecoregions in the Western United States, we will have an opportunity to conduct regional synthesis and comparison of LU/LC change characteristics from multiple ecoregions. Furthermore, we consider this study to be the first analysis in anticipation of future analyses and applications and this Land Cover Trends data, and the results from this study may be used in future studies requiring estimates of amounts and rates of regional LU/LC change. 


\section{Acknowledgments}

We would like to thank Christy Ryan for her invaluable assistance throughout the course of this study and Alicia Torregrosa and Nora Devoe for providing insightful comments on an earlier draft this report.

\section{References Cited}

Anderson, J., Hardy, E., Roach, J., and Witmer, R., 1976, A land use and land cover classification system for use with remote sensor data: U.S. Geological Survey Professional Paper 964.

Brabec, E., Schulte, S., Richards, P.L., 2002, Impervious surfaces and water quality - a review of current literature and its implications for watershed planning: Journal of Planning Literature, v. 16, n. 4, p. 243-258.

Chang, C., 1996, Ecosystem responses to fire and variations in fire regimes, in Sierra Nevada Ecosystem Project final report to Congress, vol. II, Assessments and scientific basis for management options: Davis, University of California, Centers for Water and Wildlands Research, , v. 2, c. 39, p. 1071-1099.

DeBano, L.F., 1979, Effects of fire on soil properties in Laacke, R.J., ed., California forest soils - a guide for professional foresters and resource managers and planners: University of California, Berkeley, Agricultural Sciences Publications, p. 109-118.

Duane, T.P., 1996, Human Settlement, 1850-2040, in Sierra Nevada Ecosystem Project final report to Congress, vol. II, Assessments and scientific basis for management options: Davis, University of California, Centers for Water and Wildlands Research, v. 2, c. 11, p. 235-360.

Environmental Protection Agency, 1999, Level III Ecoregions of the Continental United States: U.S. Environmental Protection Agency, National Health and Environmental Effects Research Laboratory, Corvallis, Oregon, 1:7,500,000-scale map.

Fischer, L., Rosenberg, M., Mahon, L., Liu, Z., Maurizi, B., Longmire, P., Shupe, S., 2004, Monitoring land cover changes in California, Northern Sierra project area, cycle II: State of California, Department of Forestry and Fire Protection, Sacramento, Calif.

Gallant, A.L., Loveland, T.R., Sohl, T.L., and Napton, D.E., 2004, Using an ecoregion framework to analyze land-cover and land-use dynamics: Environmental Management, v. 34, sup. 1, p. S89-S110.
Helms, J.A., and Tappeiner, J.C., 1996, Silviculture in the Sierra, in Sierra Nevada Ecosystem Project final report to Congress, vol. II, Assessments and scientific basis for management options: Davis, University of California, Centers for Water and Wildlands Research, v. 2, c. 15, p. $439-476$.

Levien, L., Fischer, C., and Maurizi, B., 1999, Monitoring land cover changes in California, Southern Sierra project area: State of California, Resources Agency, Department of Forestry and Fire Protection, Sacramento, Calif.

Loveland, T.R., Sohl, T.L., Stehman, S.V., Gallant, A.L., Sayler, K.L., and Napton, D.E., 2002, A strategy for estimating the rates of recent United States land-cover changes: Photogrammetric Engineering and Remote Sensing, v. 68, n. 10, p. 1091-1099.

Manley, P.N., Fites-Kaufman, J.A., Barbour, M.G., Schlesinger, M.D., and Rizzo, D.M., 2000, Biological integrity, in Murphy, D.D., and Knopp, C.M., eds., Lake Tahoe watershed assessment: U.S. Forest Service Pacific Southwest Research Station, Albany, Calif., Gen. Tech. Rep. PSW-GTR-175, v. 1, c. 5, p. 403-598.

McKelvey, K.S., Skinner, C.N., Chang, C., Erman, D.C., Husari, S.J., Parsons, D.J., van Wagtendonk, J.W., and Weatherspoon, C.P., 1996, An overview of fire in the Sierra Nevada, in Sierra Nevada Ecosystem Project final report to Congress, vol. II, Assessments and scientific basis for management options: Davis, University of California, Centers for Water and Wildlands Research, v. 2, c. 37, p. 1033-1040.

Nagel, T.N., and Taylor, A.H., 2005, Fire and persistence of montane chaparral in mixed conifer forest landscapes in the northern Sierra Nevada, Lake Tahoe Basin, California, USA: Journal of the Torrey Botanical Society, v. 132, n. 3, p. $442-457$.

Oliver, W.W., Ferrell, G.T., and Tappeiner, J.C., 1996, Density management of Sierra Forests in Sierra Nevada Ecosystem Project final report to Congress, vol. III, Assessments, commissioned reports, and background information: Davis, University of California, Centers for Water and Wildlands Research, v. 3, c. 11, p. 217-276.

Omernik, J.M., 1987, Ecoregions of the conterminous United States: Annals of the Association of American Geographers, v. 77 , p. 118-125.

Poff, R.J., 1996, Effects of silvicultural practices and wildfire on productivity of forest soils, in Sierra Nevada Ecosystem Project final report to Congress, vol. II, Assessments and scientific basis for management options: Davis, University of California, Centers for Water and Wildlands Research, v. 2 , c. 16, p. $477-493$. 
Ruth, L., 1996, Conservation and controversy-national forest management, 1960-95, in Sierra Nevada Ecosystem Project final report to Congress, vol. II, Assessments and scientific basis for management options: Davis, University of California, Centers for Water and Wildlands Research, v. 2, c. 7, p. 145-162.

Shevock, J.R., 1996, Status of rare and endemic plants, in Sierra Nevada Ecosystem Project final report to Congress, vol. II, Assessments and scientific basis for management options: Davis, University of California, Centers for Water and Wildlands Research, v. 2, c. 24, p. 691-707.

Skinner, C.N., and Chang, C., 1996, Fire regimes, past and present, in Sierra Nevada Ecosystem Project final report to Congress, vol. II, Assessments and scientific basis for management options: Davis, University of California, Centers for Water and Wildlands Research, v. 2, c. 38, p. 1041-1069.

Slonecker, E.T., Jennings, D.B., and Garofalo, D., 2001, Remote sensing of impervious surfaces-a review: Remote Sensing Reviews, v. 20, n. 3, p. 1231-1242.

SNEP Science Team and Special Consultants, 1996a, Sierra Nevada ecosystems, in Sierra Nevada Ecosystem Project final report to Congress, vol. I, Assessment summaries and management strategies: Davis, University of California, Centers for Water and Wildlands Research, v. 1, c. 1, p. 3-16.

SNEP Science Team and Special Consultants, 1996b, People and resource use, in Sierra Nevada Ecosystem Project final report to Congress, vol. I, Assessment summaries and management strategies: Davis, University of California, Centers for Water and Wildlands Research, v. 1, c. 2, p. 17-45.
Sohl, T.L., Gallant, A.L., and Loveland, T.R., 2004, The characteristics and interpretability of land surface change and implications for project design: Photogrammetric Engineering and Remote Sensing, v. 70, n. 4, p. 439-448.

State of California, Department of Finance, 2005, E-1 City/County Population Estimates, with Annual percent Change, January 1, 2004 and 2005: Sacramento, California, May 2005.

Stehman, S.V., Sohl, T.L., and Loveland, T.R., 2003, Statistical sampling to characterize recent United States land-cover change: Remote Sensing of Environment, v. 86, p. 517-529.

Stewart, W.C., 1996, Economic assessment of the ecosystem, in Sierra Nevada Ecosystem Project final report to Congress, vol. III, Assessments, commissioned reports, and background information: Davis, University of California, Centers for Water and Wildlands Research, v. 3, c. 23.

Stine, S., 1996, Climate, 1650-1850, in Sierra Nevada Ecosystem Project final report to Congress, vol. II, Assessments and scientific basis for management options: Davis, University of California, Centers for Water and Wildlands Research, v. 2, c. 2, p. 25-30.

Tappeiner, J.C., and McDonald, P.M., 1996, Regeneration of Sierra Nevada forests, in Sierra Nevada Ecosystem Project final report to Congress, vol. III, Assessments, commissioned reports, and background information: Davis, University of California, Centers for Water and Wildlands Research, v. 3, c. 12.

Vogelmann, J.E., Howard, S.M., Yang, L., Larson, C.R., Wylie, B.K., and van Driel, N., 2001, Completion of the 1990s National Land Cover Data Set for the conterminous United States from Landsat Thematic Mapper data and ancillary data sources: Photogrammetic Engineering and Remote Sensing, v. 67, p. 650-662. 


\section{Appendixes 1-2}




\section{Appendix 1. Definitions of land use and land cover}

The following are the land-use/land-cover (LU/LC) definitions used in the Land Cover Trends project. To the extent possible, the definitions are based on the original Anderson and others (1976) Level I definitions so that LU/LC data developed through this project are consistent with those produced through other programs and projects.

It is important to recognize that our ability to identify and map these LU/LC classes is limited by the technical specifications of Landsat MSS, TM, and ETM+ sensors and by the local and regional landscape characteristics that affect the form and contrast of LU/LC characteristics. Thus, consistent and accurate detection of fine-scale patterns and features will sometimes be difficult.

1. Water - Areas persistently covered with water, such as streams, canals, lakes, reservoirs, bays, or oceans.

2. Developed - Areas of intensive use with much of the land covered with structures and/or anthropogenic impervious surfaces (for example, high-density residential, commercial, industrial, or transportation) or less intensive uses where the land-cover matrix includes both vegetation and structures (e.g., low-density residential, recreational facilities, cemeteries, transportation and utility corridors, etc.), including any land functionally related to the developed or built-up activity.

3. Mechanically disturbed - Land in an altered and often unvegetated state that, due to disturbances by mechanical means, is in transition from one cover type to another. Mechanical disturbances include forest clear-cutting, earthmoving, scraping, chaining, reservoir drawdown, and other similar human-induced changes.

4. Mining - Areas with extractive mining activities that have a significant surface expression. This includes (to the extent that these features can be detected) mining buildings, quarry pits, overburden, leach, evaporative, tailing, or other related components.

5. Barren - Land comprised of soils, sand, or rocks where less than 10 percent of the area is vegetated. Barren lands are usually naturally occurring.

6. Forest - Tree-covered land where the tree cover density is greater than 10 percent. Note that cleared forest land (i.e., clearcuts) will be mapped according to current cover (for example, mechanically disturbed or shrubland/grassland).

7. Grassland/Shrubland - Land predominately covered with grasses, forbs, or shrubs. The vegetated cover must comprise at least 10 percent of the area.

8. Agriculture - Land in either a vegetated or unvegetated state used for the production of food and fiber. This includes cultivated and uncultivated croplands, hay lands, pasture, orchards, vineyards, and confined livestock operations. Note that forest plantations are considered forests regardless of the use of the wood products.

9. Wetland - Lands where water saturation is the determining factor in soil characteristics, vegetation types, and animal communities. Wetlands are comprised of water and vegetated cover.

10. Nonmechanically disturbed - Land in an altered and often unvegetated state that, due to disturbances by nonmechanical means, is in transition from one cover type to another. Nonmechanical disturbances are caused by wind, floods, fire, animals, and other similar phenomenon.

11. Snow/Ice - Land where the accumulation of snow and ice does not completely melt during the summer period (that is, perennial). 


\section{Appendix 2. Period contingency tables}

The following tables show matrices describing land-use/land-cover change area and direction by period. All of the tables and graphs describing amounts and rates of land-use/land-cover change in the Results section of this report can be produced using the data in these contingency tables with the exception of footprint of change.

1973 to 1980 :

\begin{tabular}{|c|c|c|c|c|c|c|c|c|c|c|c|c|}
\hline $\mathbf{k m}^{2}$ & Wat. & Dev. & M.Dis. & Mini. & N.Bar. & $\begin{array}{c}1973 \\
\text { Fore. }\end{array}$ & Gr./Sh. & Agri. & Wetl. & N.M.Di. & Sn./lce & Total \\
\hline Wat. & 605.5 & 0 & 0 & 0 & 0 & 0 & 0 & 0 & 0 & 0 & 0 & 605.5 \\
\hline Dev. & 0 & 126.6 & 0 & 0 & 0 & 0 & 0 & 0 & 0 & 0 & 0 & 126.6 \\
\hline M.Dis. & 6.4 & 0 & 0 & 0 & 0 & 58.4 & 0 & 0 & 0 & 0 & 0 & 64.8 \\
\hline Mini. & 0 & 0 & 0 & 73.5 & 0 & 0 & 0 & 0 & 0 & 0 & 0 & 73.5 \\
\hline o N.Bar. & 0 & 0 & 0 & 0 & 1446.0 & 0 & 0 & 0 & 0 & 0 & 0 & 1446.0 \\
\hline ळ Fore. & 0 & 0 & 0 & 0 & 0 & 39104.0 & 0 & 0 & 0 & 0 & 0 & 39104.0 \\
\hline Gr./Sh. & 0 & 0 & 191.2 & 0 & 0 & 0 & 10258.0 & 0 & 0 & 84.4 & 0 & 10533.5 \\
\hline Agri. & 0 & 0 & 0 & 0 & 0 & 0 & 0 & 160.1 & 0 & 0 & 0 & 160.1 \\
\hline Wetl. & 0 & 0 & 0 & 0 & 0 & 0 & 0 & 0 & 1175.3 & 0 & 0 & 1175.3 \\
\hline N.M.Di. & 0 & 0 & 0 & 0 & 0 & 111.7 & 1.0 & 0 & 1.1 & 0 & 0 & 113.8 \\
\hline Sn./lce & 0 & 0 & 0 & 0 & 0 & 0 & 0 & 0 & 0 & 0 & 9.9 & 9.9 \\
\hline Total & 611.9 & 126.6 & 191.2 & 73.5 & 1446.0 & 39274.1 & 10259.0 & 160.1 & 1176.5 & 84.4 & 9.9 & 53413.0 \\
\hline
\end{tabular}

1980 to 1986 :

\begin{tabular}{|c|c|c|c|c|c|c|c|c|c|c|c|c|}
\hline $\mathbf{k m}^{2}$ & Wat. & Dev. & M.Dis. & Mini. & N.Bar. & $\begin{array}{l}1980 \\
\text { Fore. }\end{array}$ & Gr./Sh. & Agri. & Wetl. & N.M.Di. & Sn./lce & Total \\
\hline Wat. & 605.5 & 0 & 0 & 0 & 0 & 0 & 0 & 0 & 0 & 0 & 0 & 605.5 \\
\hline Dev. & 0 & 126.6 & 0 & 0 & 0 & 0 & 0 & 0 & 0 & 0 & 0 & 126.6 \\
\hline M.Dis. & 0 & 0 & 6.4 & 0 & 0 & 146.2 & 0 & 0 & 0 & 0 & 0 & 152.6 \\
\hline Mini. & 0 & 0 & 0 & 73.5 & 0 & 0 & 0 & 0 & 0 & 0 & 0 & 73.5 \\
\hline o N.Bar. & 0 & 0 & 0 & 0 & 1446.0 & 0 & 0 & 0 & 0 & 0 & 0 & 1446.0 \\
\hline \& Fore. & 0 & 0 & 4.2 & 0 & 0 & 38877.8 & 81.4 & 0 & 0 & 2.8 & 0 & 38966.2 \\
\hline Gr./Sh. & 0 & 0 & 54.2 & 0 & 0 & 0 & 10452.2 & 0 & 0 & 109.9 & 0 & 10616.2 \\
\hline Agri. & 0 & 0 & 0 & 0 & 0 & 0 & 0 & 160.1 & 0 & 0 & 0 & 160.1 \\
\hline Wetl. & 0 & 0 & 0 & 0 & 0 & 0 & 0 & 0 & 1254.9 & 1.1 & 0 & 1256.0 \\
\hline N.M.Di. & 0 & 0 & 0 & 0 & 0 & 0.5 & 0 & 0 & 0 & 0 & 0 & 0.5 \\
\hline Sn./lce & 0 & 0 & 0 & 0 & 0 & 0 & 0 & 0 & 0 & 0 & 9.9 & 9.9 \\
\hline Total & 605.5 & 126.6 & 64.8 & 73.5 & 1446.0 & 39024.5 & 10533.5 & 160.1 & 1254.9 & 113.8 & 9.9 & 53413.0 \\
\hline
\end{tabular}

1986 to $1992:$

\begin{tabular}{|c|c|c|c|c|c|c|c|c|c|c|c|c|}
\hline $\mathbf{k m}^{2}$ & Wat. & Dev. & M.Dis. & Mini. & N.Bar. & $\begin{array}{c}1986 \\
\text { Fore. }\end{array}$ & Gr./Sh. & Agri. & Wetl. & N.M.Di. & Sn./lce & Total \\
\hline Wat. & 592.4 & 0 & 0 & 0 & 0 & 0 & 0 & 0 & 0 & 0 & 0 & 592.4 \\
\hline Dev. & 0 & 126.6 & 0 & 0 & 0 & 2.2 & 0 & 0 & 0 & 0 & 0 & 128.8 \\
\hline M.Dis. & 13.1 & 0 & 6.4 & 0 & 0 & 391.1 & 0 & 0 & 0 & 0 & 0 & 410.6 \\
\hline Mini. & 0 & 0 & 0 & 73.5 & 0 & 0 & 0 & 0 & 0 & 0 & 0 & 73.5 \\
\hline N N.Bar. & 0 & 0 & 0 & 0 & 1446.0 & 0 & 0 & 0 & 0 & 0 & 0 & 1446.0 \\
\hline รั Fore. & 0 & 0 & 0 & 0 & 0 & 38470.8 & 190.2 & 0 & 0 & 0 & 0 & 38661.1 \\
\hline Gr./Sh. & 0 & 0 & 146.2 & 0 & 0 & 0 & 10403.4 & 0 & 0 & 0.5 & 0 & 10550.1 \\
\hline Agri. & 0 & 0 & 0 & 0 & 0 & 0 & 0 & 160.1 & 0 & 0 & 0 & 160.1 \\
\hline Wetl. & 0 & 0 & 0 & 0 & 0 & 0 & 0 & 0 & 1256.0 & 0 & 0 & 1256.0 \\
\hline N.M.Di. & 0 & 0 & 0 & 0 & 0 & 102.0 & 22.6 & 0 & 0 & 0 & 0 & 124.6 \\
\hline Sn./lce & 0 & 0 & 0 & 0 & 0 & 0 & 0 & 0 & 0 & 0 & 9.9 & 9.9 \\
\hline Total & 605.5 & 126.6 & 152.6 & 73.5 & 1446.0 & 38966.2 & 10616.2 & 160.1 & 1256.0 & 0.5 & 9.9 & 53413.0 \\
\hline
\end{tabular}




\section{Appendix 2. Period contingency tables-Continued}

1992 to 2000:

\begin{tabular}{|c|c|c|c|c|c|c|c|c|c|c|c|c|}
\hline $\mathbf{k m}^{2}$ & Wat. & Dev. & M.Dis. & Mini. & N.Bar. & $\begin{array}{l}1992 \\
\text { Fore. }\end{array}$ & Gr./Sh. & Agri. & Wetl. & N.M.Di. & Sn./lce & Total \\
\hline Wat. & 586.3 & 0 & 0.1 & 0 & 0 & 0 & 0 & 0 & 0 & 0 & 0 & 586.4 \\
\hline Dev. & 0 & 128.8 & 0 & 0 & 0 & 3.4 & 5.1 & 10.4 & 0 & 0 & 0 & 147.6 \\
\hline M.Dis. & 6.2 & 0 & 19.4 & 0 & 0 & 187.8 & 0.9 & 0 & 0.3 & 0 & 0 & 214.5 \\
\hline Mini. & 0 & 0 & 0 & 73.5 & 0 & 0 & 0 & 0 & 0 & 0 & 0 & 73.5 \\
\hline o N.Bar. & 0 & 0 & 0 & 0 & 1446.0 & 0 & 0 & 0 & 0 & 0 & 0 & 1446.0 \\
\hline 응 Fore. & 0 & 0 & 29.7 & 0 & 0 & 37359.3 & 31.3 & 0 & 0 & 7.0 & 0 & 37427.3 \\
\hline${ }^{\sim}$ Gr./Sh. & 0 & 0 & 361.4 & 0 & 0 & 0 & 10398.9 & 0 & 0 & 112.0 & 0 & 10872.3 \\
\hline Agri. & 0 & 0 & 0 & 0 & 0 & 0 & 2.1 & 149.7 & 0 & 0 & 0 & 151.8 \\
\hline Wetl. & 0 & 0 & 0 & 0 & 0 & 0 & 0 & 0 & 1176.2 & 0 & 0 & 1176.2 \\
\hline N.M.Di. & 0 & 0 & 0 & 0 & 0 & 1190.1 & 111.7 & 0 & 0 & 5.6 & 0 & 1307.5 \\
\hline Sn./Ice & 0 & 0 & 0 & 0 & 0 & 0 & 0 & 0 & 0 & 0 & 9.9 & 9.9 \\
\hline Total & 592.4 & 128.8 & 410.6 & 73.5 & 1446.0 & 38740.6 & 10550.1 & 160.1 & 1176.5 & 124.6 & 9.9 & 53413.0 \\
\hline
\end{tabular}

Explanation of land-use/land-cover class abbreviations used in period contingency tables:

Wat., Water

Dev., Developed

M.Dis., Mechanically disturbed

Mini., Mining

Bar., Barren

Fore., Forest

Gr./Sh., Grassland/Shrubland

Agri., Agriculture

Wetl., Wetland

N.M.Di., Nonmechanically disturbed

Sn./Ice, Snow/Ice 


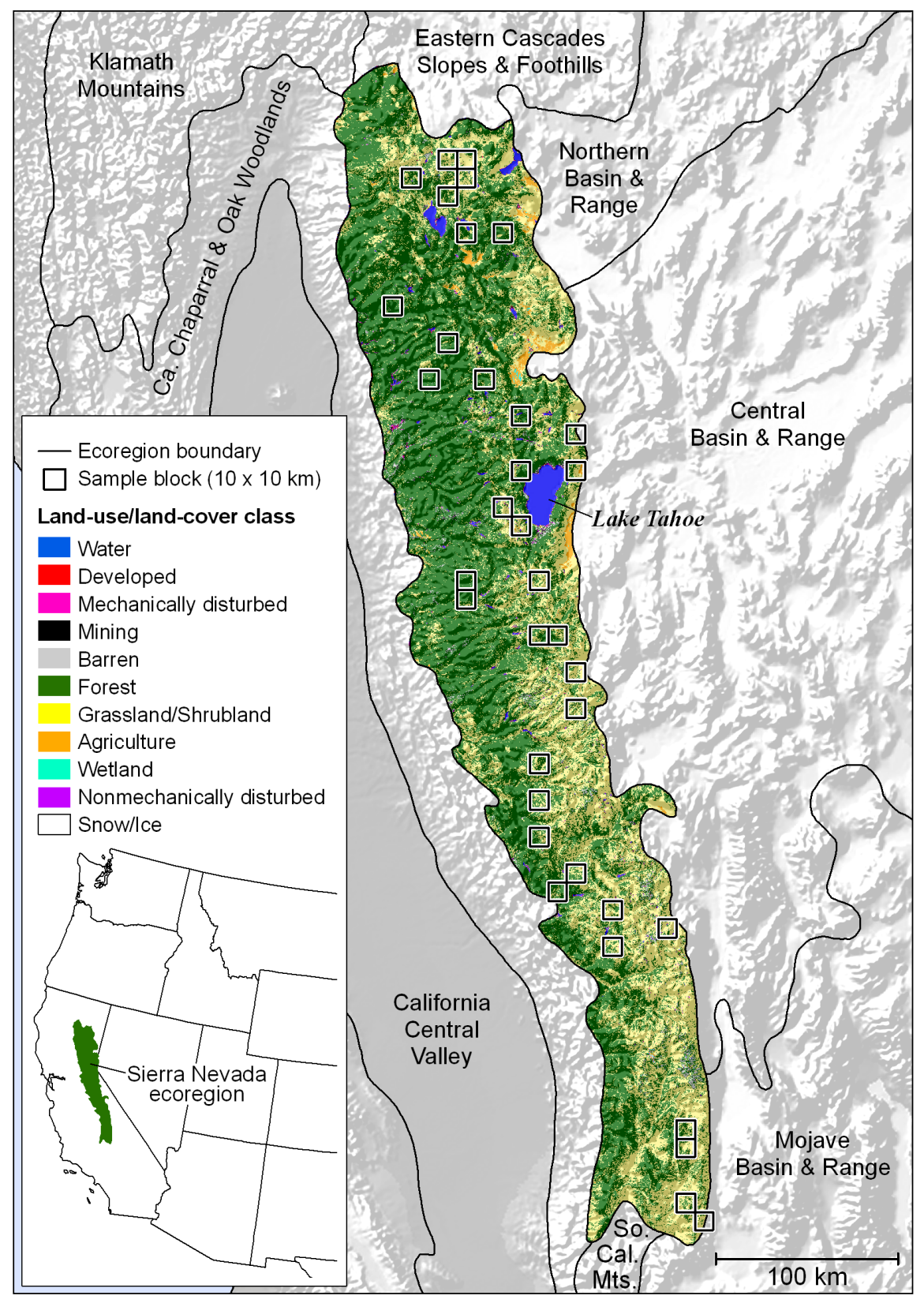

Figure 1. Sierra Nevada and surrounding ecoregions. Land-use/land-cover data shown for the Sierra Nevada ecoregion is from the 1992 National Land Cover Dataset (Vogelmann and others, 2001). The $36100-\mathrm{km}^{2}$ sample blocks were randomly selected. 


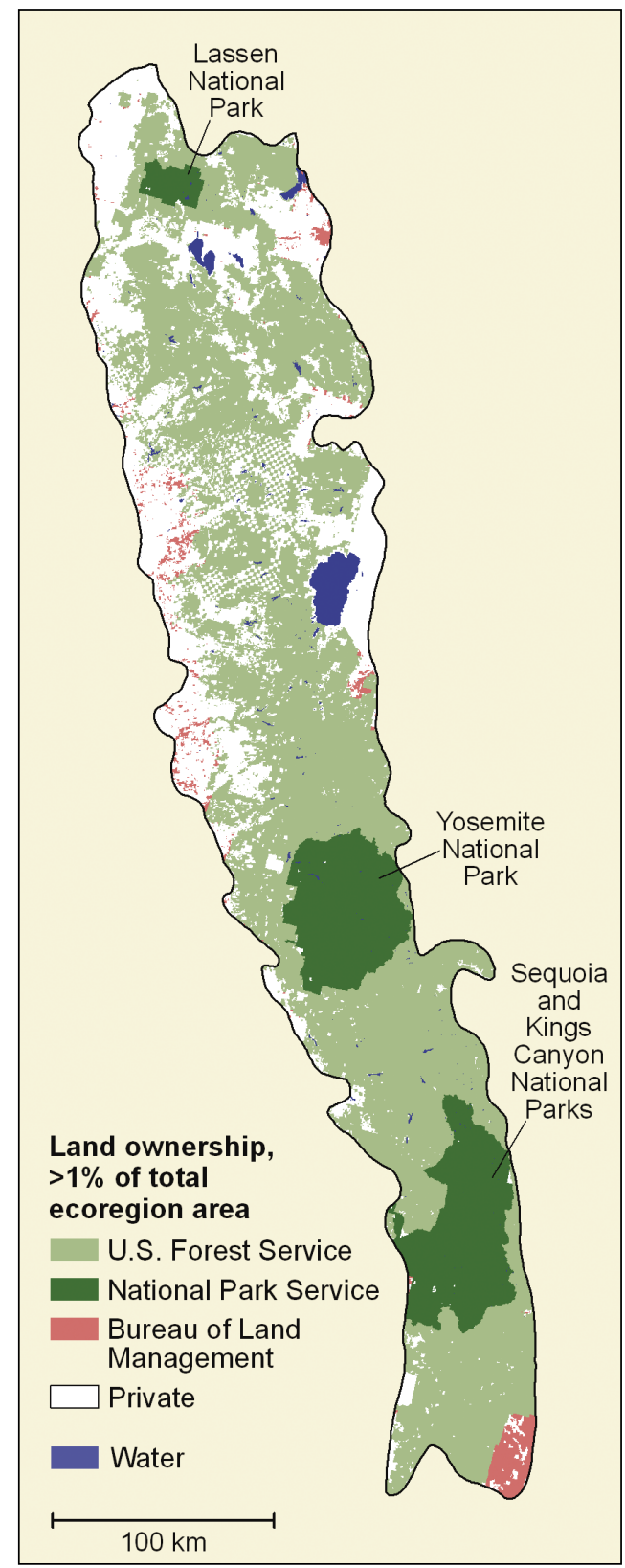

Figure 2. Land ownership in the Sierra Nevada ecoregion for ownership groups having greater than 1 percent of total ecoregion area. Ownership data is from the California Resources Agency Legacy Project dated August 7, 2003. 

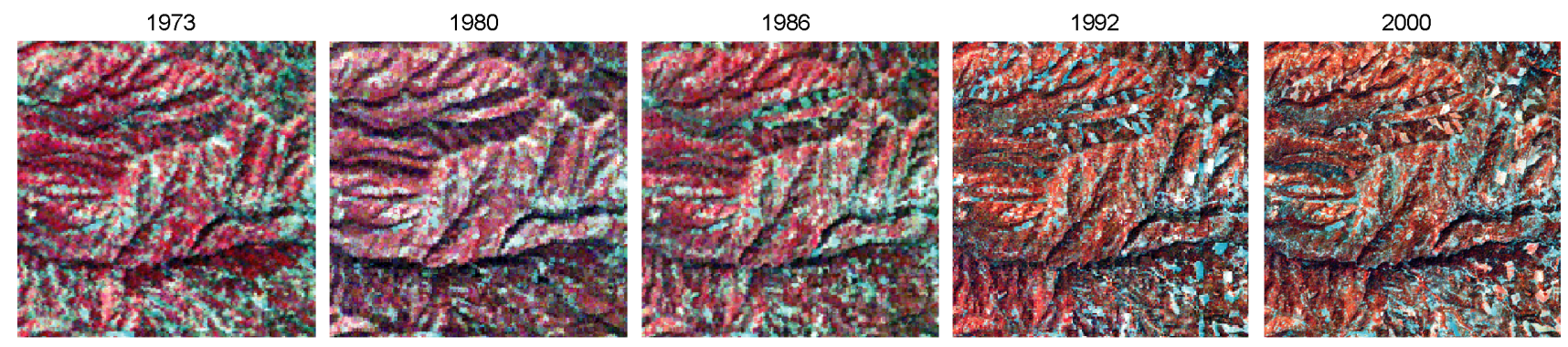

Above: Landsat satellite imagey (false-color composites, bands 4-2-1)
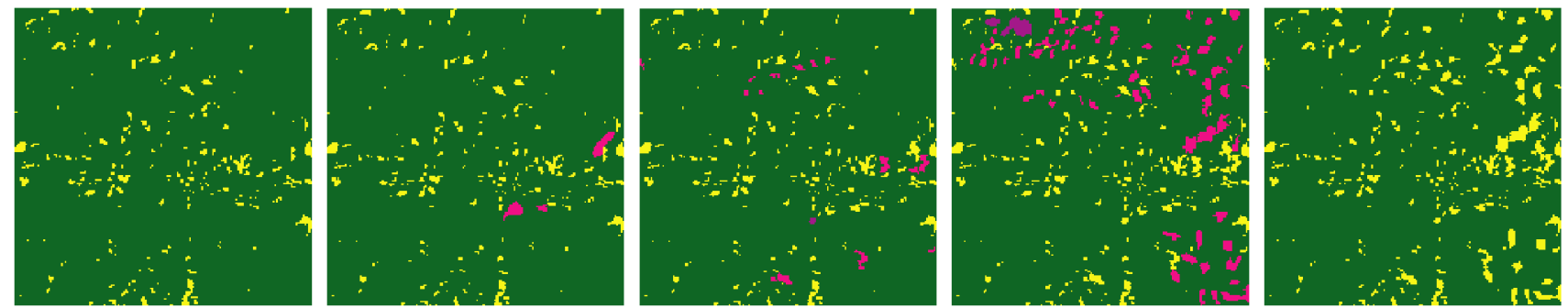

Above: Land-cover images visually interpreted from Landsat satellite imagery. Land-cover types are as follows:

Forest Grass/Shrubland Mechanically disturbed (harvested) Nonmechanically disturbed (burned)
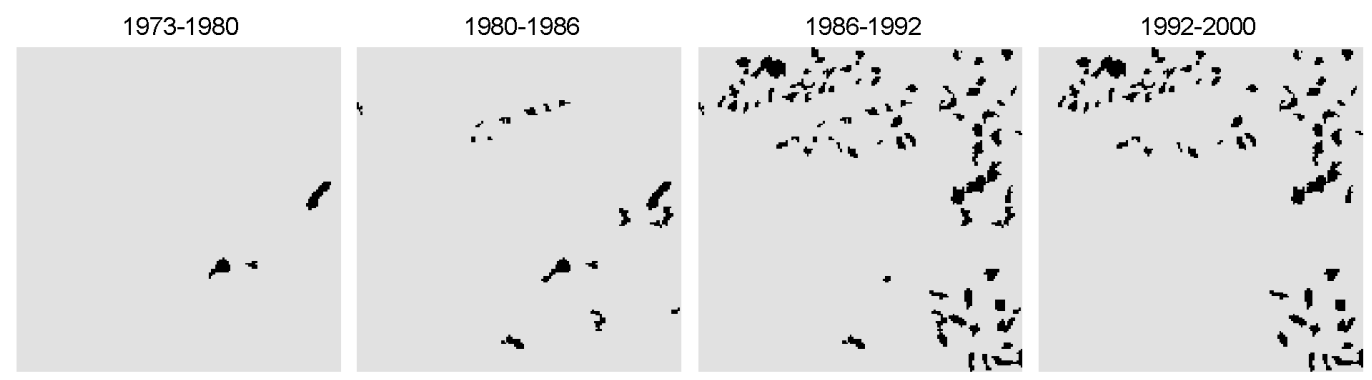

Above: Land-cover change images for each period showing areas of change in black

Figure 3. A single $100-\mathrm{km}^{2}$ sample block illustrating land-cover change resulting from timber harvest, fire, and subsequent forest regeneration. Most of this sample block (90 percent) is located within the Eldorado National Forest in the central Sierra Nevada ecoregion. 


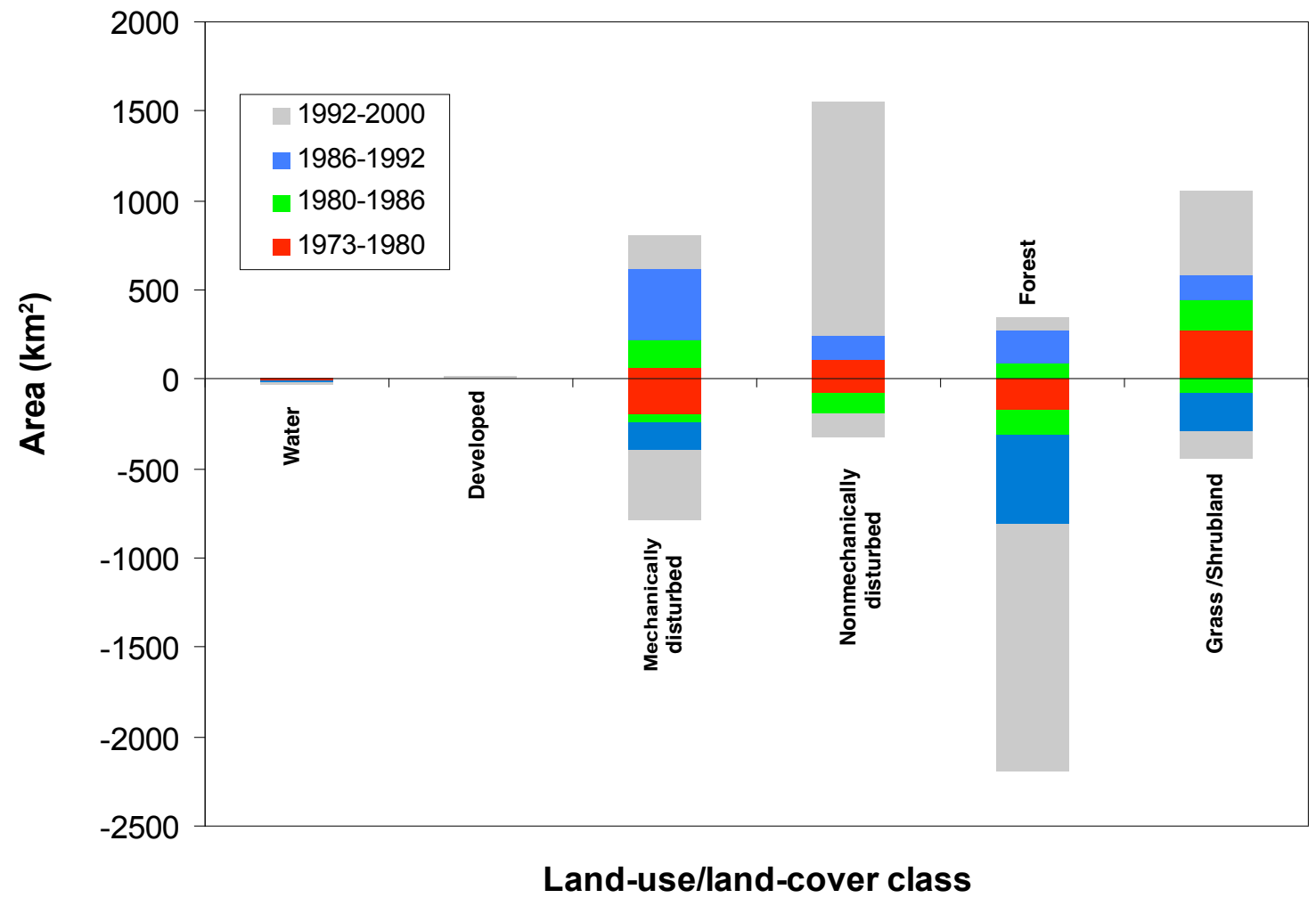

Figure 4. Gross change (area gained and lost) by class by period in the Sierra Nevada ecoregion. Class area gained is shown by positive values and class area lost is shown by negative values. No changes were detected to the mining, snow/ice, and barren classes and consequently are not listed here. 

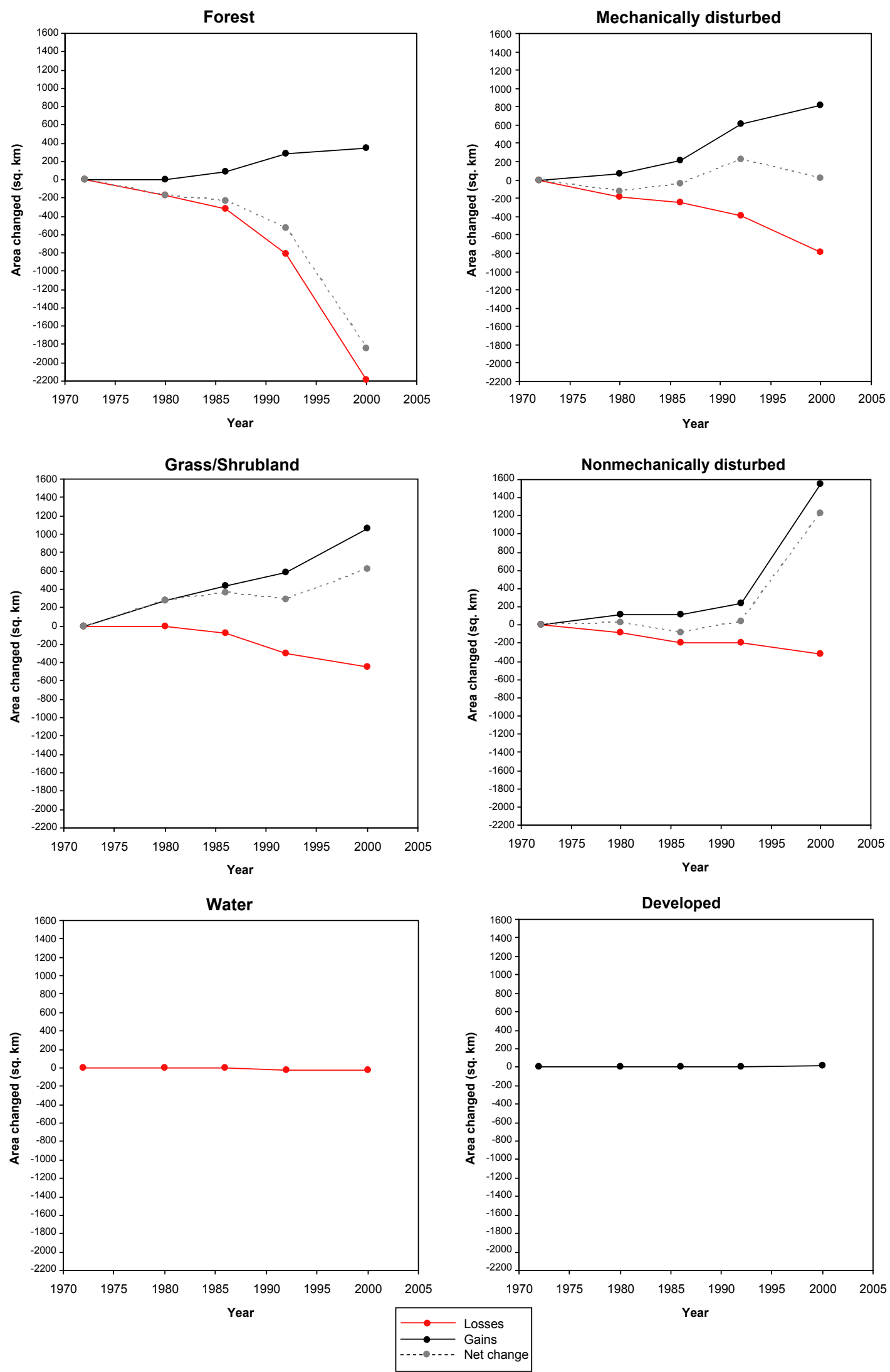

Figure 5. Temporal variability of individual land-use/land-cover classes in the Sierra Nevada ecoregion from 1973 to 2000 shown by cumulative area gained, area lost, and net change (gains minus losses). 


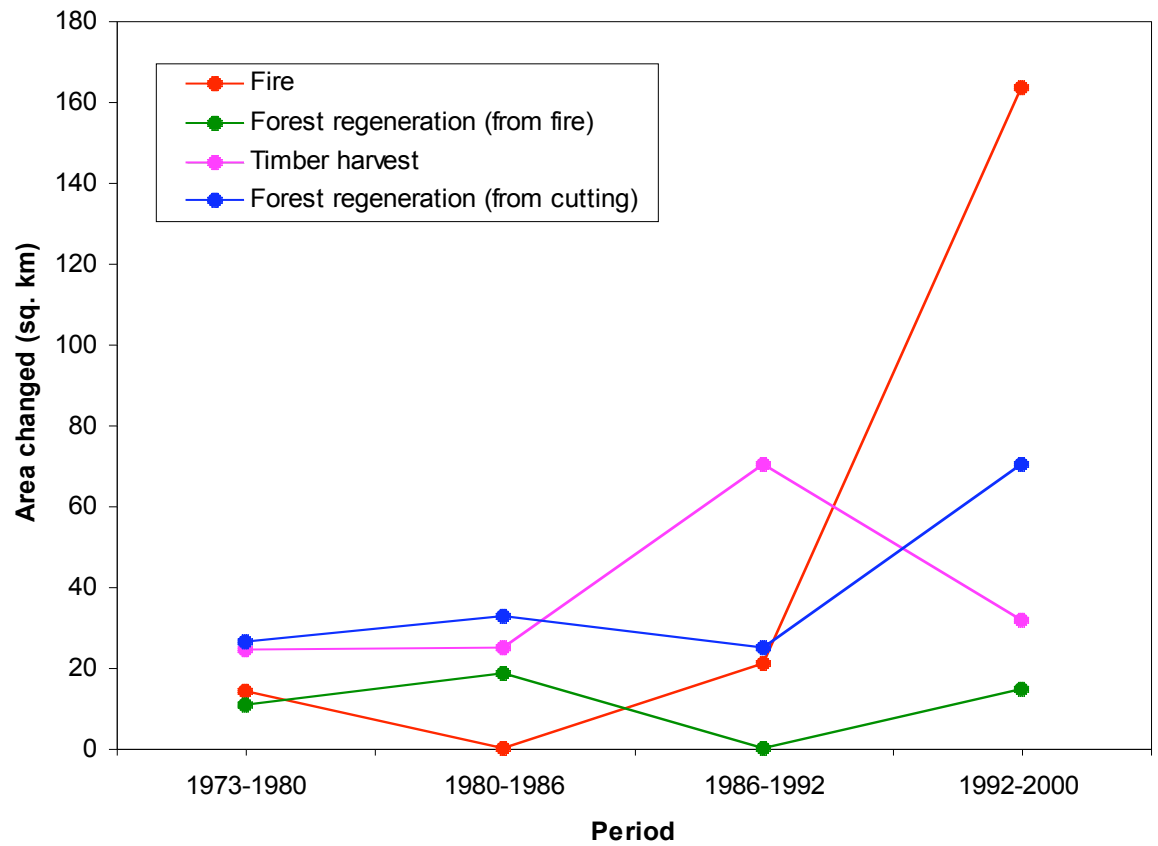

Figure 6. Forest area changed in the Sierra Nevada ecoregion by fire, timber harvest, and regeneration during each period. 


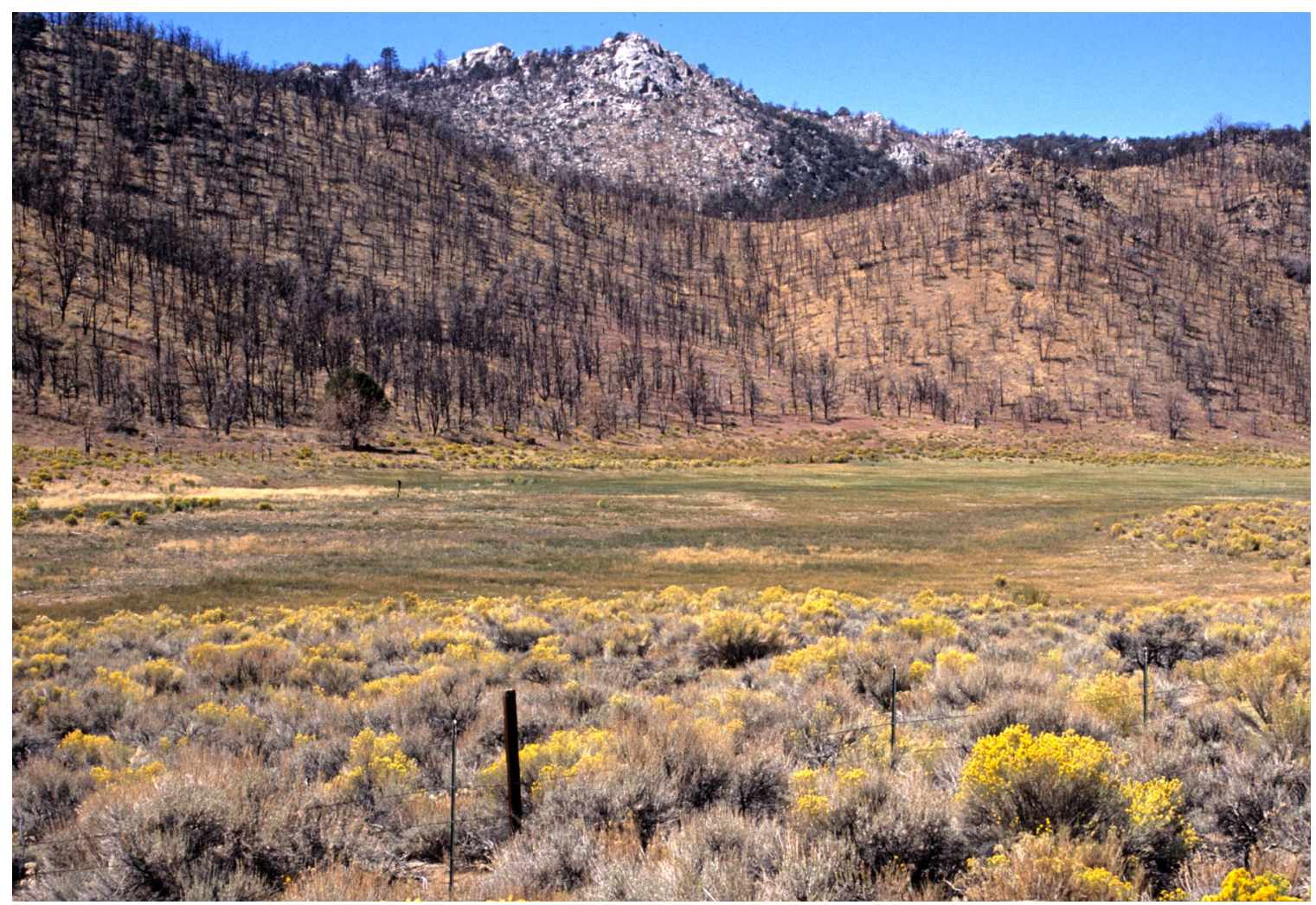

Figure 7. Photo taken September 2004 of an area (background slope) undergoing regeneration that was burned by the Manter Fire on the southern end of the Sierra Nevada ecoregion in Sequoia National Forest, Tulare County, Calif. The Manter Fire ignited on July 22, 2000 and burned about $300 \mathrm{~km}^{2}$. Land-cover types shown are forest, grass/shrubland, and wetland. 


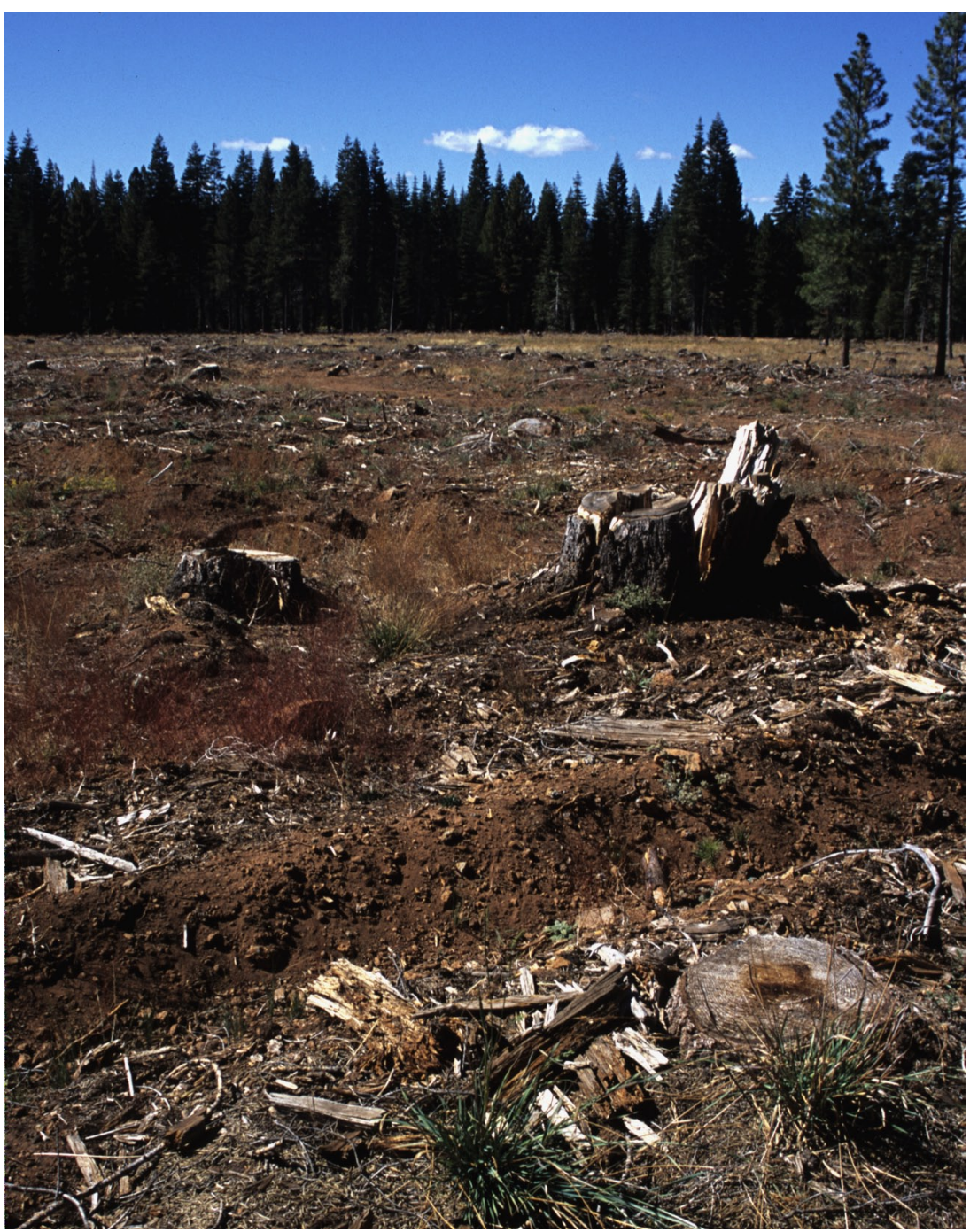

Figure 8. Recently clear-cut area in Plumas National Forest, Plumas County, Calif. Land-cover types shown are forest and mechanically disturbed. 


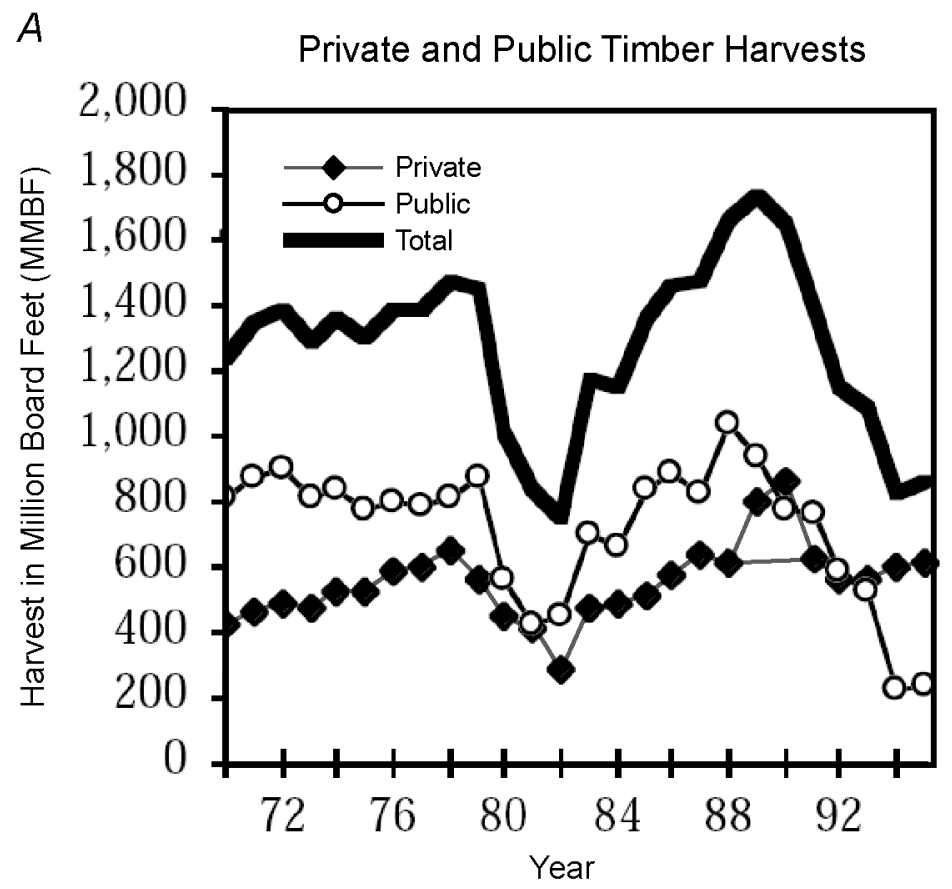

$B$

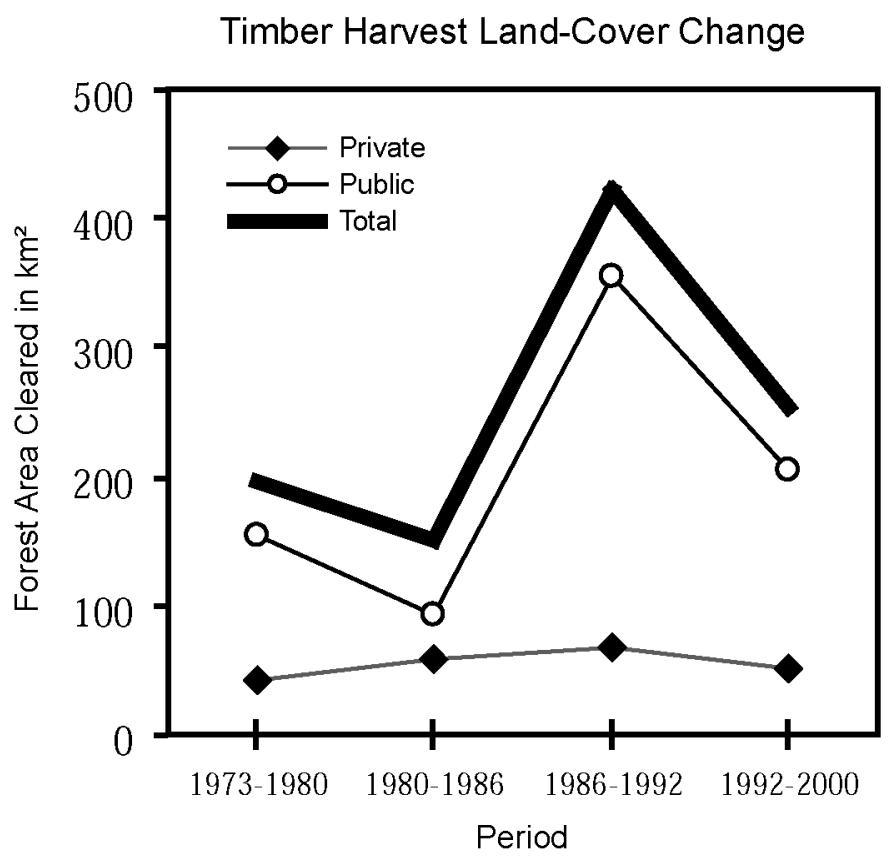

Figure 9. Comparison of timber harvest and land-cover change data for the Sierra Nevada ecoregion. $A$, Timber harvest data by year reported by the United States Forest Service and California State Board of Equalization for the period 1970-1995 (adapted from Stewart, 1996). B, Land-cover change data from analysis describing timber harvest (forest conversion to mechanically disturbed) by period for the Sierra Nevada ecoregion. 


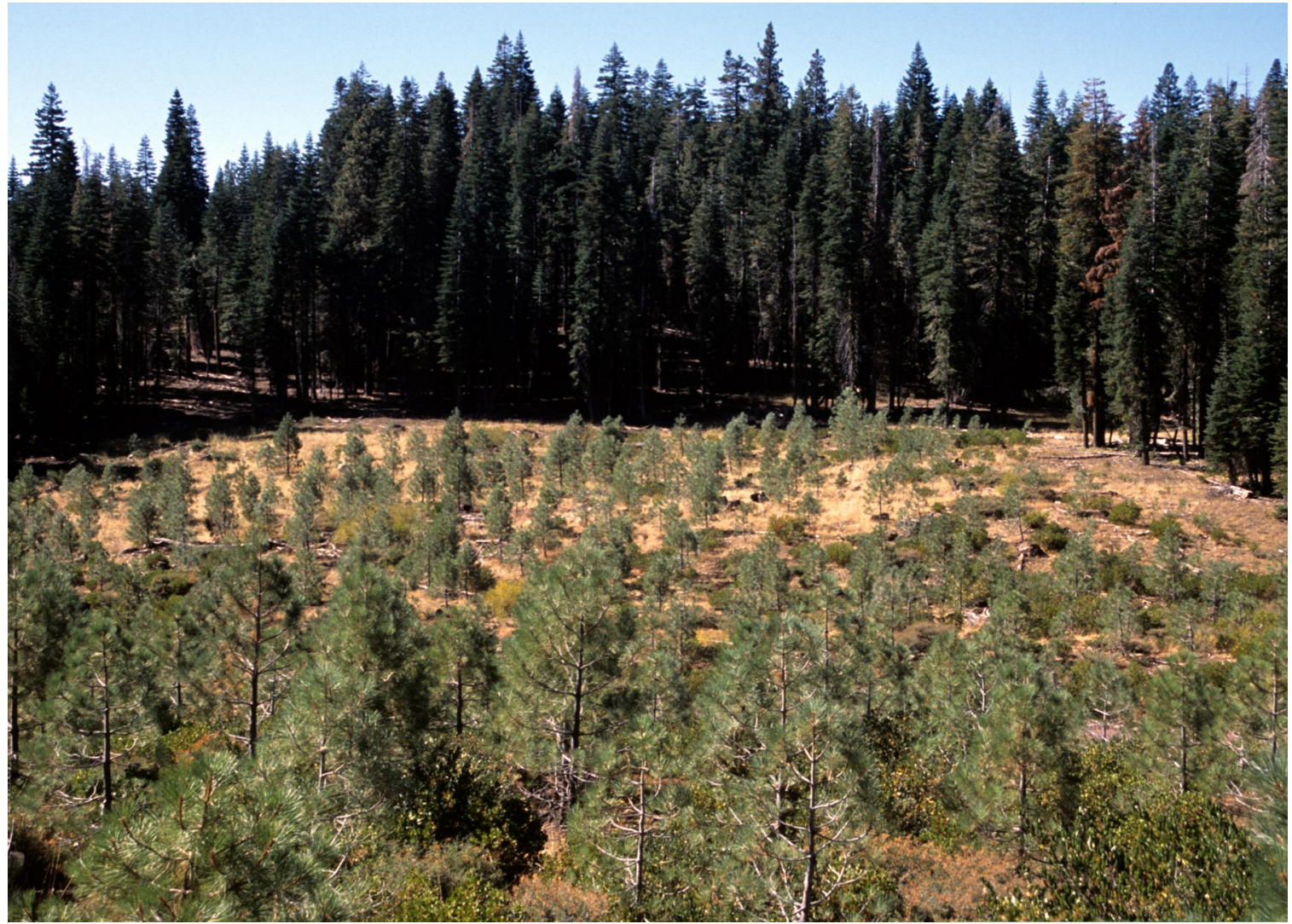

Figure 10. Forest regeneration after seeding, Plumas National Forest. Land-cover types shown are forest and grass/shrubland.

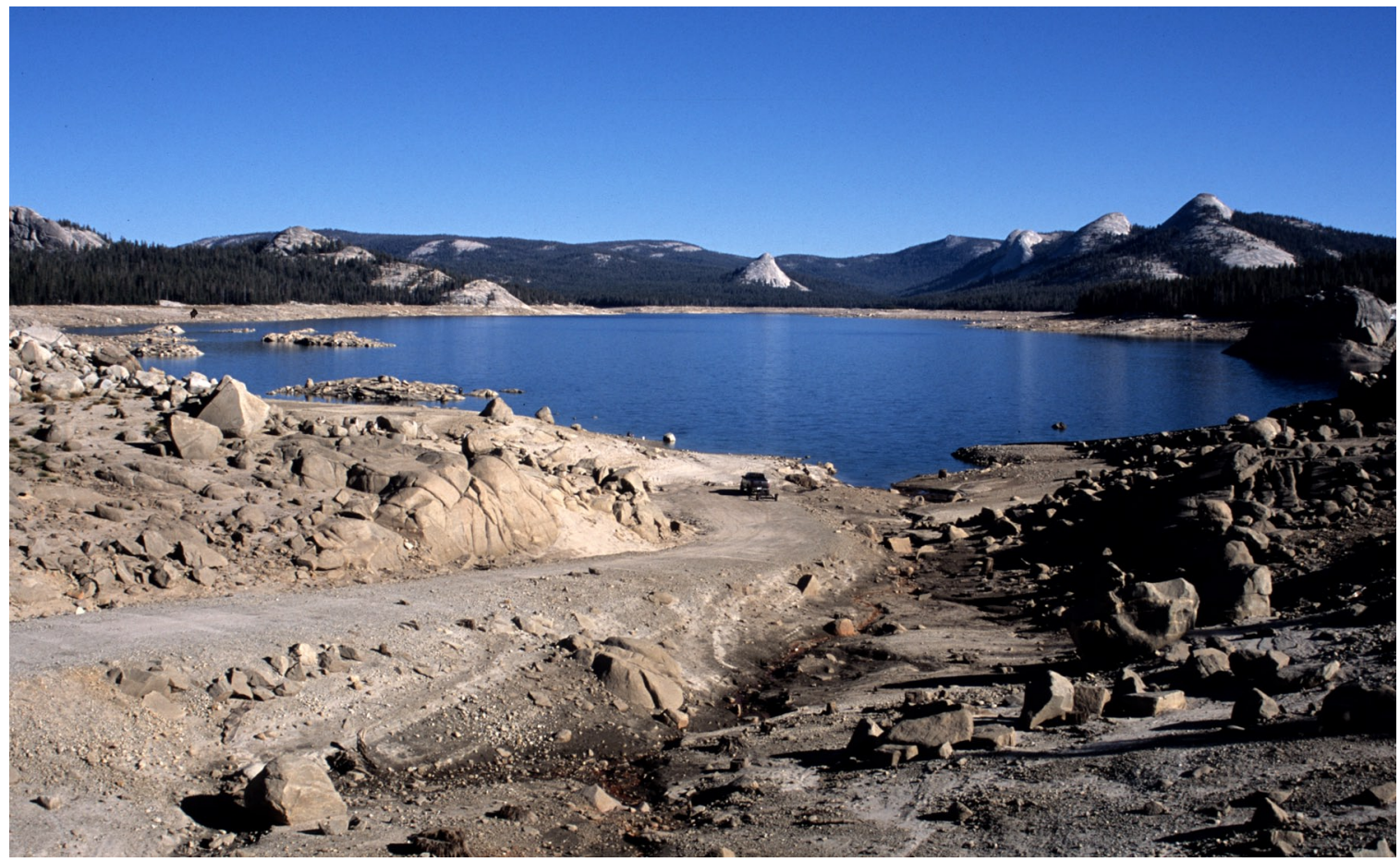

Figure 11. Courtright Reservoir in Sierra National Forest, Fresno County, Calif., exhibited lowered surface levels by late summer (Sept. 2004). Land-cover types shown are forest, barren, and mechanically disturbed. 


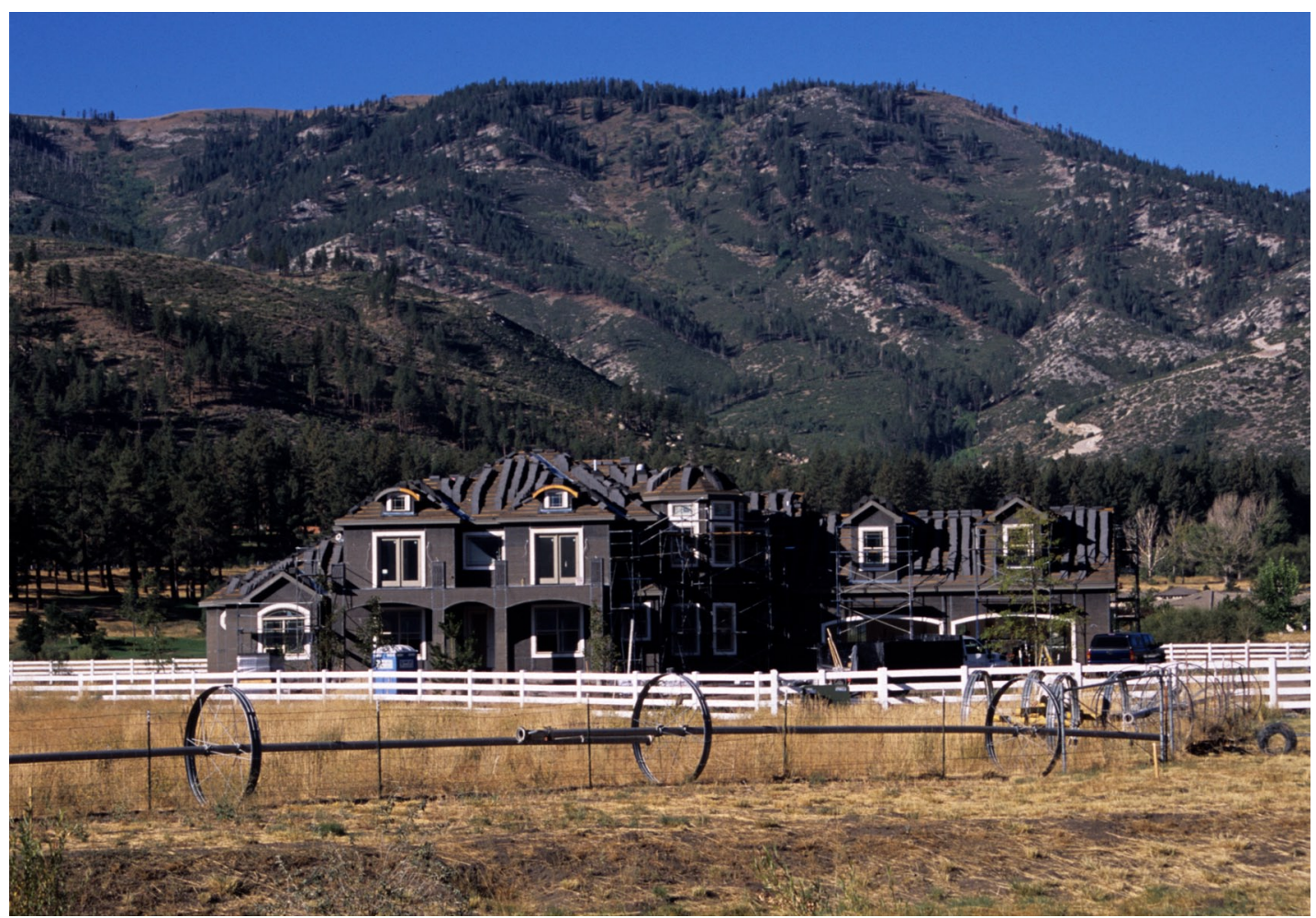

Figure 12. New residential construction in Franktown, Nev., about $1 \mathrm{~km}$ west of the eastern boundary of the Sierra Nevada ecoregion and north of Carson City. Land-cover types shown are forest, grass/shrubland, developed, and agriculture.

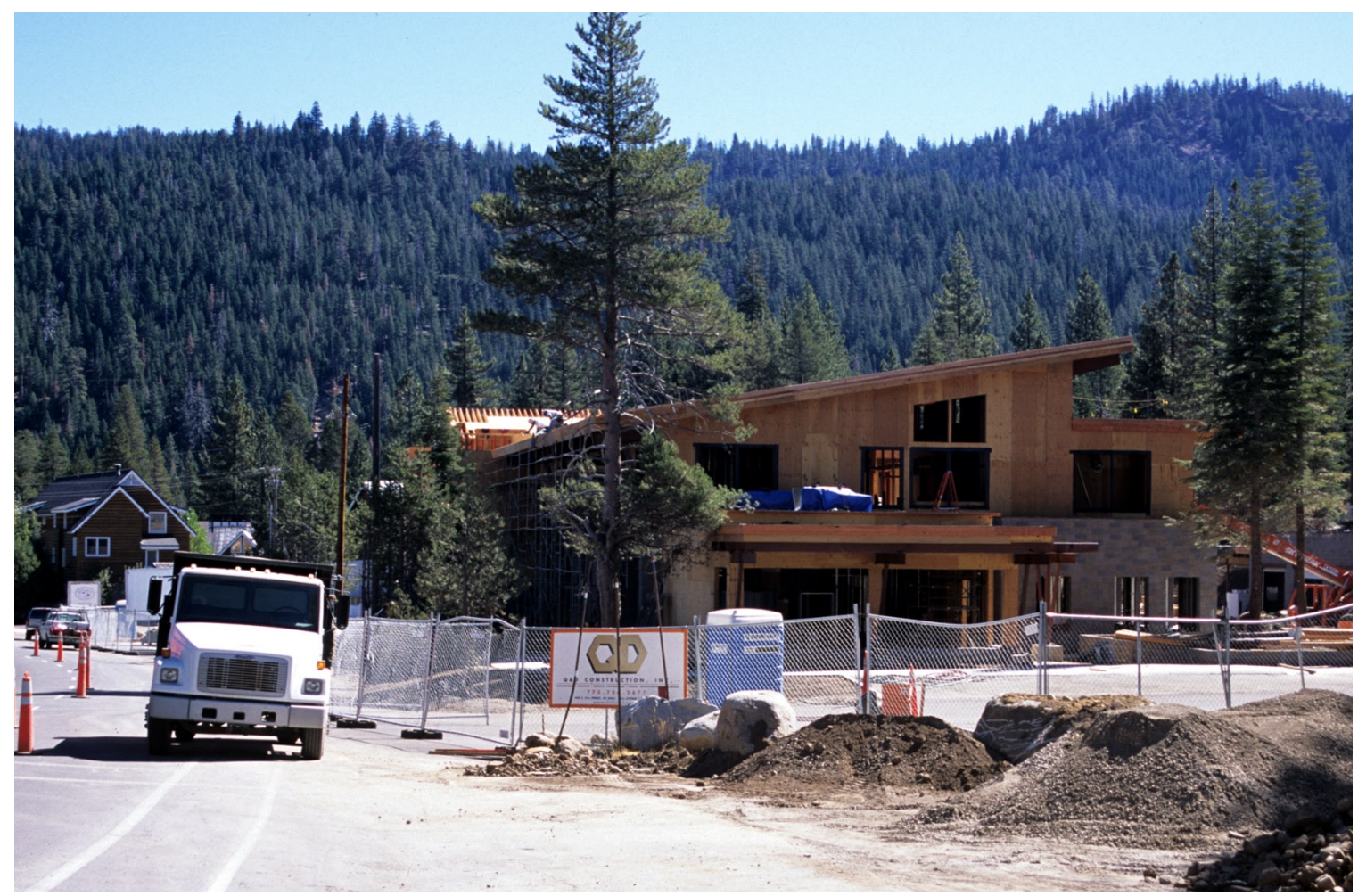

Figure 13. Commercial construction along the access road to the Squaw Valley resort area near Lake Tahoe, Calif. Land-cover types shown are forest and developed. 


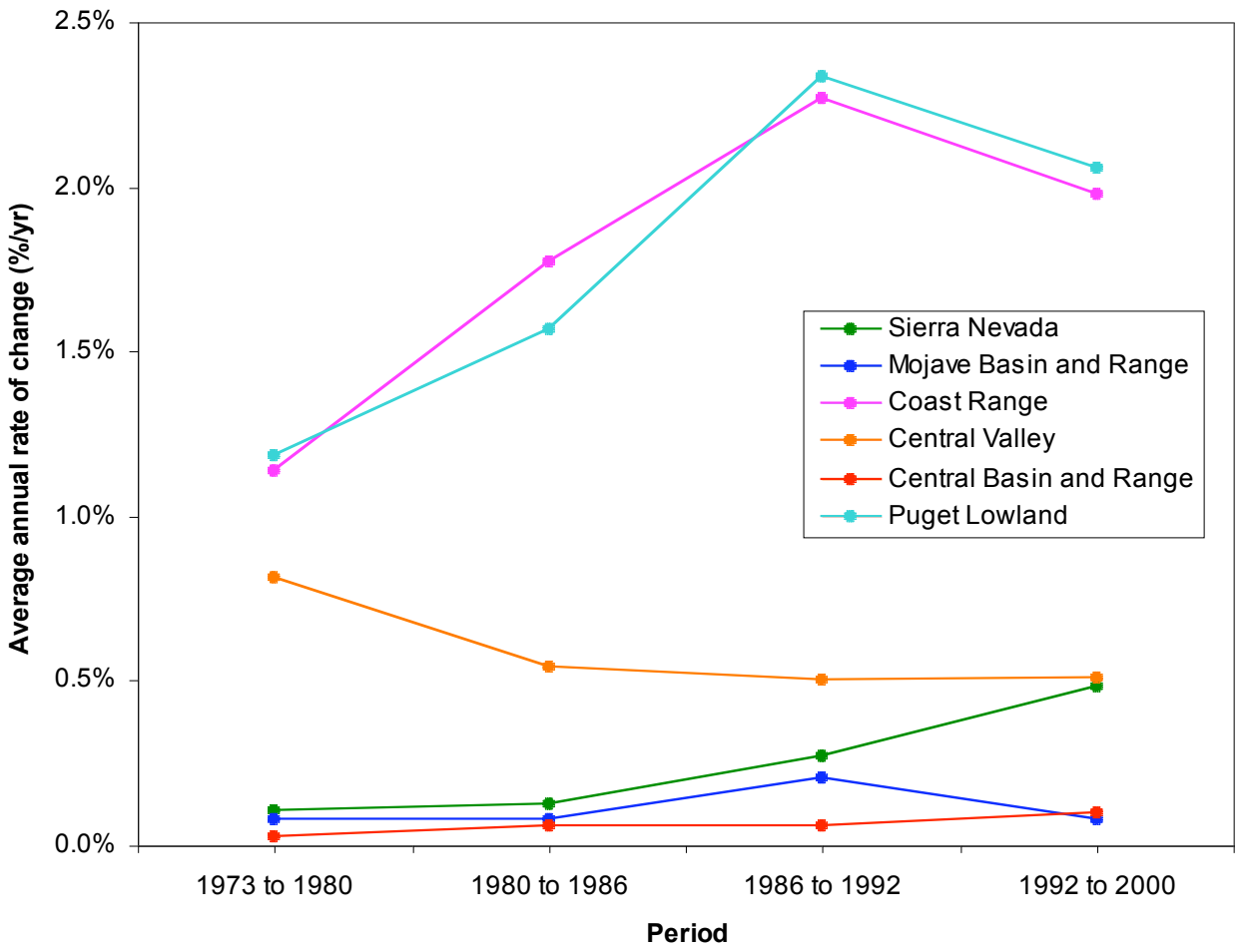

Figure 14. Average annual rates of change by period for selected ecoregions in the Western United States. These ecoregions were chosen for comparison based on their relative proximity to the Sierra Nevada ecoregion and the availability of completed Land Cover Trends analysis data. 
1992
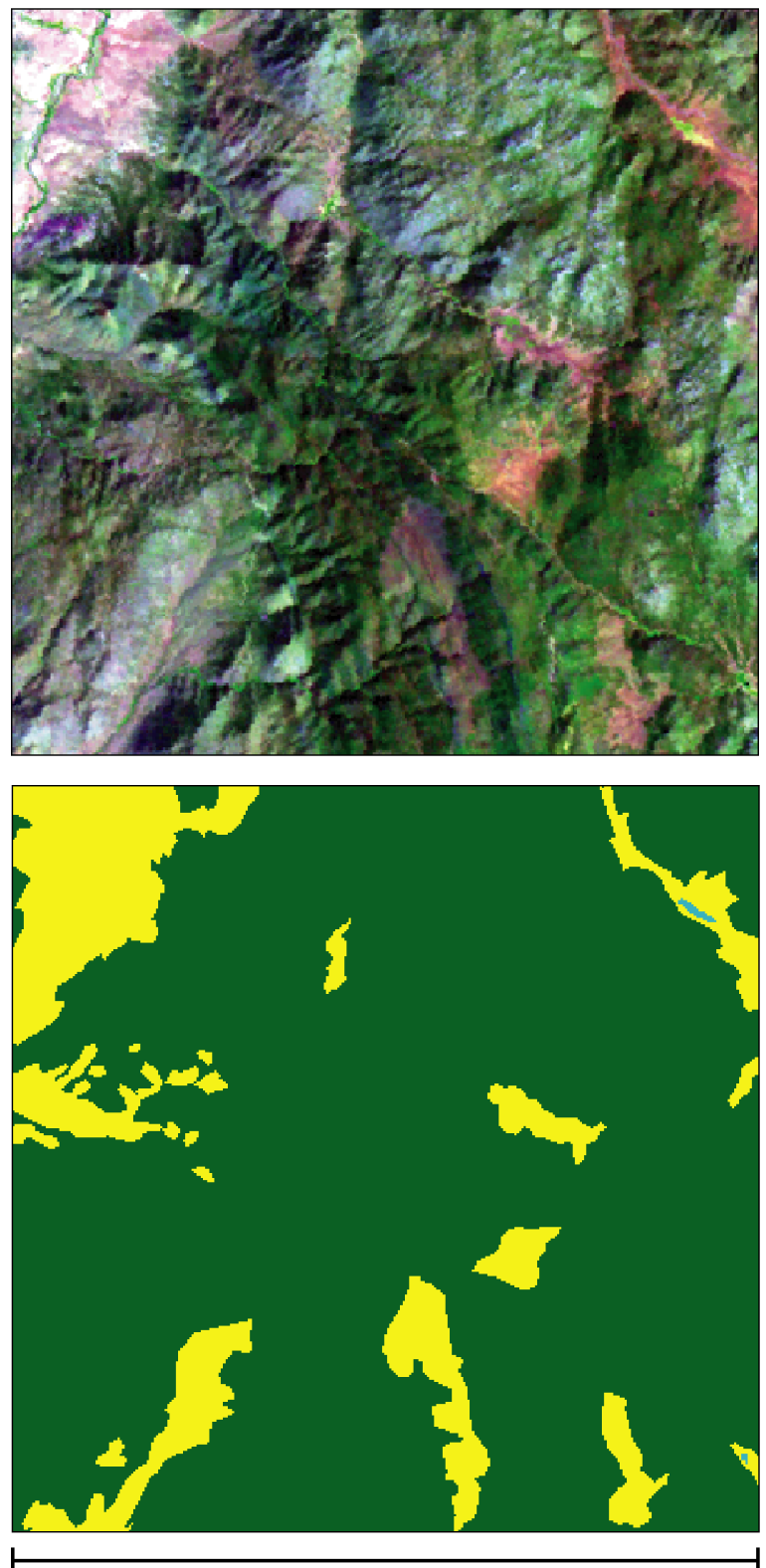

$10 \mathrm{~km}$
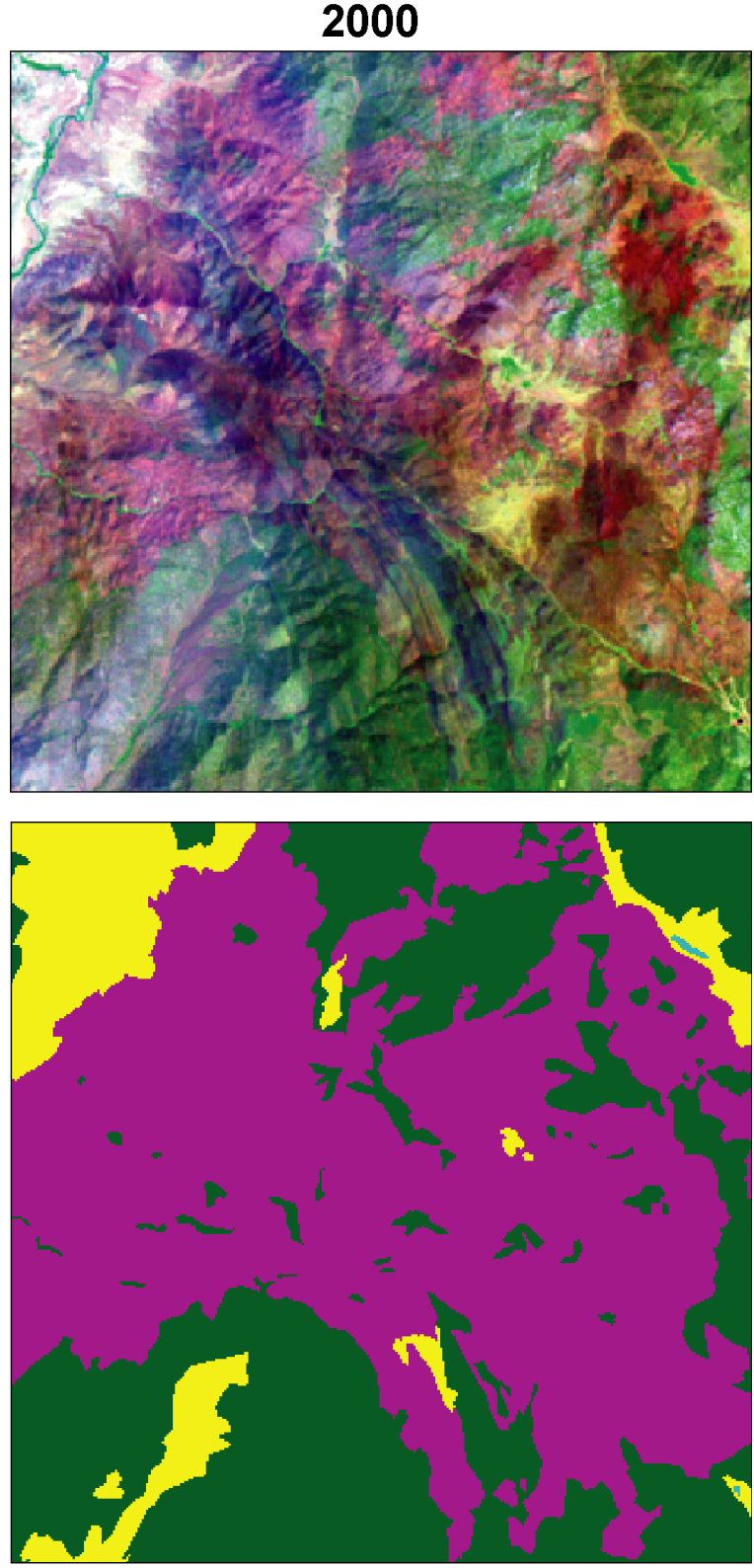

Forest $\square$ Grass/Shrubland

Wetland $\square$ Nonmechanically disturbed (burned)

Figure 15. Example of extensive land-cover change within a sample block during a single period (1992-2000) caused by wildfire in the southern Sierra Nevada ecoregion. The two top images are Landsat Thematic Mapper false-color composites (bands 7-4-1) and the bottom images are the corresponding visually interpreted land-cover maps. The Manter Fire of July 2000 burned 56.4 percent of this $100-\mathrm{km}^{2}$ sample block. 
Table 1. Land-use/land-cover class area by date as a percent of Sierra Nevada ecoregion total area $\left(52,872 \mathrm{~km}^{2}\right)$.

[Net change is the difference in area between beginning and end dates of the study period (1973 and 2000) which may mask changes that occurred during the intermediate periods. Net change by class is shown in terms of class area $\left(\mathrm{km}^{2}\right)$ changed, percent of ecoregion changed, and percent of a class's 1973 area changed]

\begin{tabular}{|c|c|c|c|c|c|c|c|c|}
\hline \multirow[b]{2}{*}{ Land-use/land-cover class } & \multirow[b]{2}{*}{1973} & \multirow[b]{2}{*}{1980} & \multirow[b]{2}{*}{1986} & \multirow[b]{2}{*}{1992} & \multirow[b]{2}{*}{2000} & \multicolumn{3}{|c|}{ Net change, $1973-2000$} \\
\hline & & & & & & $\mathbf{k m}^{2}$ & $\begin{array}{l}\text { Percent of } \\
\text { ecoregion }\end{array}$ & $\begin{array}{l}\text { Percent of } \\
1973 \text { class area }\end{array}$ \\
\hline Water & 1.1 & 1.1 & 1.1 & 1.1 & 1.1 & -25.3 & 0.0 & -4.2 \\
\hline Developed & 0.2 & 0.2 & 0.2 & 0.2 & 0.3 & +20.9 & 0.0 & +16.6 \\
\hline Mechanically disturbed & 0.4 & 0.1 & 0.3 & 0.8 & 0.4 & +7.7 & 0.0 & +3.7 \\
\hline Mining & 0.1 & 0.1 & 0.1 & 0.1 & 0.1 & 0.0 & 0.0 & 0.0 \\
\hline Naturally barren & 2.7 & 2.7 & 2.7 & 2.7 & 2.7 & 0.0 & 0.0 & 0.0 \\
\hline Forest & 73.5 & 73.1 & 73.0 & 72.5 & 70.1 & -1812.2 & -3.4 & -4.7 \\
\hline Grass/Shrubland & 19.2 & 19.7 & 19.9 & 19.8 & 20.4 & +603.8 & +1.1 & +5.9 \\
\hline Agriculture & 0.3 & 0.3 & 0.3 & 0.3 & 0.3 & -8.2 & 0.0 & -5.2 \\
\hline Wetland & 2.2 & 2.3 & 2.4 & 2.2 & 2.2 & -0.3 & 0.0 & 0.0 \\
\hline Nonmechanically disturbed & 0.2 & 0.2 & 0.0 & 0.2 & 2.4 & +1210.7 & +2.3 & +1449.6 \\
\hline
\end{tabular}

Table 2. Most common land-use/land-cover conversions in the Sierra Nevada ecoregion from 1973-2000 affecting greater than $5 \mathrm{~km}^{2}$ ranked by greatest to least area changed; changes were also aggregated based on how a single or a group of similar "to" or "from" classes were affected.

[Mech., mechanically; Nonmech., nonmechanically]

\begin{tabular}{cllrr}
\hline Rank & From class & To class & $\begin{array}{r}\text { Area converted } \\
\mathbf{k m}^{\mathbf{2}} \mathbf{)}\end{array}$ & $\begin{array}{r}\text { Percent of all } \\
\text { conversions }\end{array}$ \\
\hline 1 & Forest & Nonmech. disturbed & 1404 & 37.1 \\
2 & Forest & Mech. disturbed & 784 & 20.7 \\
3 & Mech. disturbed & Grass/Shrubland & 753 & 19.9 \\
4 & Nonmech. disturbed & Grass/Shrubland & 307 & 8.1 \\
5 & Grass/Shrubland & Forest & 303 & 8.0 \\
6 & Grass/Shrubland & Nonmech. disturbed & 135 & 3.6 \\
7 & Mech. disturbed & Forest & 34 & 0.9 \\
8 & Water & Mech. disturbed & 26 & 0.7 \\
9 & Agriculture & Developed & 10 & 0.3 \\
10 & Nonmech. disturbed & Forest & 10 & 0.3 \\
11 & Nonmech. disturbed & Nonmech. disturbed & 6 & 0.1 \\
12 & Forest & Developed & 6 & 0.1 \\
13 & Grass/Shrubland & Developed & 5 & 0.1 \\
\cline { 2 - 5 } Aggregated: & & 3782 & 100.0 \\
& All classes & Nonmech. disturbed & 1545 & \\
& Mech. disturbed & Vegetation classes & 787 & \\
& Nonmech. disturbed & Vegetation classes & 316 & \\
\cline { 2 - 5 } & All classes & Developed & 21 & \\
\hline
\end{tabular}




\section{Land-Cover Trends of the Sierra Nevada Ecoregion, 1973-2000}

Table 3. Rates of land-use/land-cover change for the Sierra Nevada ecoregion grouped according to the general process that the conversions and corresponding rates describe.

[Dashes (-) are used to show rates that equal zero $\mathrm{km}^{2} / \mathrm{yr}$ in order to highlight rates greater than zero. Regen., regeneration; Mech., mechanically; Nonmech., nonmechanically]

\begin{tabular}{|c|c|c|c|c|c|c|}
\hline \multirow[b]{2}{*}{ Cause } & \multicolumn{2}{|c|}{ Land-use/land-cover class } & \multirow{2}{*}{$\begin{array}{r}1972-1980 \\
\mathrm{~km}^{2} / \mathrm{yr}\end{array}$} & \multirow{2}{*}{$\begin{array}{r}1980-1986 \\
\mathrm{~km}^{2} / \mathrm{yr}\end{array}$} & \multirow{2}{*}{$\begin{array}{r}1986-1992 \\
\mathrm{~km}^{2} / \mathrm{yr} \\
\end{array}$} & \multirow{2}{*}{$\begin{array}{r}1992-2000 \\
\mathrm{~km}^{2} / \mathrm{y}\end{array}$} \\
\hline & From class & To class & & & & \\
\hline Fire & Forest & Nonmech. disturbed & 14 & $<1$ & 17 & 149 \\
\hline$"$ & Grass/Shrubland & Nonmech. disturbed & $<1$ & - & 4 & 14 \\
\hline \multirow[t]{2}{*}{$"$} & Nonmech. disturbed & Nonmech. disturbed & - & - & - & 1 \\
\hline & & Total for cause & 14 & $<1$ & 21 & 163 \\
\hline Forest regeneration & Nonmech. disturbed & Grass/Shrubland & 11 & 18 & $<1$ & 14 \\
\hline \multirow[t]{2}{*}{ (from fire) } & Nonmech. disturbed & Forest & - & $<1$ & - & 1 \\
\hline & & Total for cause & 11 & 18 & $<1$ & 15 \\
\hline Timber harvest & Forest & Mech. disturbed & 24 & 25 & 70 & 32 \\
\hline Forest regeneration & Mech. disturbed & Grass/Shrubland & 26 & 32 & 25 & 65 \\
\hline \multirow[t]{2}{*}{ (from harvet) } & Mech. disturbed & Forest & & 1 & & 5 \\
\hline & & Total for cause & 26 & 32 & 25 & 70 \\
\hline Regen. (intermediate) & Grass/Shrubland & Forest & - & 13 & 9 & 23 \\
\hline
\end{tabular}


Table 4. Potential explanatory variables and corresponding data sources to be tested in statistical analysis of land-use/landcover change.

\begin{tabular}{ll}
\hline Potential explanatory variable & Data source \\
\hline Percent private ownership & California Resources Agency Legacy Project (2003) \\
Average percent forest cover, 1973-2000 & Land Cover Trends sample block interpretations \\
Average percent grass/shrubland cover, 1973-2000 & Land Cover Trends sample block interpretations \\
Average percent developed cover, 1973-2000 & Land Cover Trends sample block interpretations \\
Latitude & Map coordinates \\
Longitude & Map coordinates \\
Average elevation & USGS National Elevation Dataset \\
Average percent slope & USGS National Elevation Dataset \\
\hline
\end{tabular}

Table 5. Results of multiple linear regression analysis for the response variable mean gross change.

\begin{tabular}{lrrrr}
\hline Explanatory variable & Coefficient & Standard error & t-value & p-value \\
\hline Percent private ownership & 0.06 & 0.01 & 5.18 & 0.00 \\
Average percent forest cover & 0.02 & 0.01 & 2.34 & 0.03 \\
Average percent developed cover & 0.34 & 0.17 & 2.01 & 0.05 \\
Intercept & 1.37 & 0.71 & 1.92 & 0.06 \\
\hline
\end{tabular}

$\mathrm{n}=36$

$\mathrm{R}^{2}=0.58$

$\mathrm{F}=14.58$

Residual standard error $=1.05$

Model equation:

mean gross change $=(-1.37)+0.06$ (perc. private ownership) +0.02 (avg. perc. forest $)-0.34$ (avg. perc. developed)

Table 6. Gross change by period as a percentage of total Sierra Nevada ecoregion area and the corresponding margins of error at an 85-percent confidence level.

\begin{tabular}{lrr}
\hline Period & $\begin{array}{r}\text { Gross } \\
\text { change }\end{array}$ & $\begin{array}{r}\text { Margin of error } \\
\mathbf{8 5 \%} \text { conf. interval }\end{array}$ \\
\hline $1973-1980$ & $0.9 \%$ & $+/-0.5 \%$ \\
$1980-1986$ & $0.7 \%$ & $+/-0.4 \%$ \\
$1986-1992$ & $1.6 \%$ & $+/-0.5 \%$ \\
$1992-2000$ & $3.9 \%$ & $+/-2.5 \%$ \\
$1973-2000$ & $1.8 \%$ & $+/-0.7 \%$ \\
\hline
\end{tabular}

